\title{
Evidences of the presence of old continental basement in Cheju volcanic Island, South Korea, revealed by radiometric ages and $\mathrm{Nd}-\mathrm{Sr}$ isotopes of granitic rocks
}

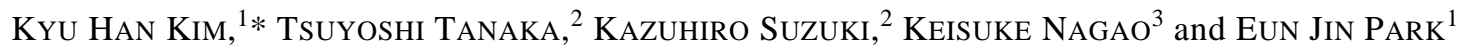 \\ ${ }^{1}$ Department of Science Education, Ewha Womans University, Seoul 120-750, South Korea \\ ${ }^{2}$ Division of Earth and Environmental Sciences, Nagoya University, Nagoya 464-8602, Japan \\ ${ }^{3}$ Laboratory for Earthquake Chemistry, University of Tokyo, Tokyo 113-0033, Japan
}

(Received October 12, 2001; Accepted March 27, 2002)

\begin{abstract}
Major and trace element and $\mathrm{Nd}-\mathrm{Sr}$ isotopic data are presented on the granitic rocks known as a basement in the Cheju volcanic island, together with CHIME age data on porphyritic hornblende-biotite granite xenolith from the Byeoldobong area.

The CHIME ages from zircon and allanite grains of porphyritic hornblende-biotite granite were determined to be $169 \pm 29 \mathrm{Ma}$ and $183 \pm 40 \mathrm{Ma}$, respectively, which are corresponding to a Jurassic age. It is concordant with a K-Ar age of $172.4 \pm 5.2 \mathrm{Ma}$ of a biotite granite in the same area, which is comparable to the Daebo granite in the Korean peninsula.

Granitic xenoliths from the Byeoldobong area have Nd-Sr isotopic compositions (initial ratio $\left({ }^{143} \mathrm{Nd} /\right.$ $\left.{ }^{144} \mathrm{Nd}\right) \mathrm{i}=0.51156 \sim 0.51158, \varepsilon_{\mathrm{Nd}}=-19 \sim-14$ and $\left.\left({ }^{87} \mathrm{Sr} /{ }^{86} \mathrm{Sr}\right) \mathrm{i}=0.7156 \sim 0.7164, \varepsilon_{\mathrm{Sr}}=101 \sim 179\right)$ which are close to those of Jurassic Daebo granite $\left(\varepsilon_{\mathrm{Nd}}=-21 \sim-14, \varepsilon_{\mathrm{Sr}}=104 \sim 171\right)$. On the other hand, the micrographic granite from the drilling core in the Hadeokcheon area gives initial ratio $\left({ }^{143} \mathrm{Nd} /{ }^{144} \mathrm{Nd}\right) \mathrm{i}=0.51218$ and $\left.\left({ }^{87} \mathrm{Sr} /{ }^{86} \mathrm{Sr}\right) \mathrm{i}=0.7077\right)$, which are comparable to the Cretaceous Bulguksa granite ranging from 0.51184 to 0.51268 in ${ }^{143} \mathrm{Nd} /{ }^{144} \mathrm{Nd}$ and 0.7055 to 0.7167 in ${ }^{87} \mathrm{Sr} /{ }^{86} \mathrm{Sr}$. The $\mathrm{T}^{\mathrm{Nd}}{ }_{\mathrm{DM}}$ model ages of 1.0 to $1.7 \mathrm{Ga}$ from the Mesozoic granitic plutons in the Cheju island suggest that the source materials of the plutons in the island have evolved since mid-Proterozoic time as those of the peninsula.

In combination with the basement geology and petrochemistry, $\mathrm{Nd}-\mathrm{Sr}$ isotopes, and radiometric and model ages of granitic rocks, our results imply that the Okchon zone is continuously extended to the Cheju volcanic Island of the southeastern end of the continental margin of the Eurasian plate.
\end{abstract}

\section{INTRODUCTION}

The Cheju Island is a typical shield volcano located on the continental margin at the southern end of the Korean peninsula. The alkali volcanic rocks of the Cheju Island erupted between Pleistocene (1.2 Ma) and Holocene (AD 1570) (Won et al., 1986; Yun et al., 1987; Lee et al., 1988; Min et al., 1988).

The volcanic succession consists mainly of basaltic lava flows and pyroclastic rocks. No basement rock crop out on the surface. The basement rock has previously been assumed to be made of volcanic and granitic rocks of the Cretaceous which lie at $c a$. 250 300 m below sea level (Lee, 1982; Yoon, 1997). It has been thought to be an extension of the Kyoungsang sedimentary basin in the peninsula (Haraguchi, 1929; Lee, 1982; Yoon, 1997). The age and kind of the concealed basement rocks in Cheju volcanic island provide useful information on the geotectonic division of the Korean peninsula and characteristics of continental margin occurred intensive igneous activities including the Mesozoic plutonism and the

*Corresponding author (e-mail: kyuhan@ewha.ac.kr) 


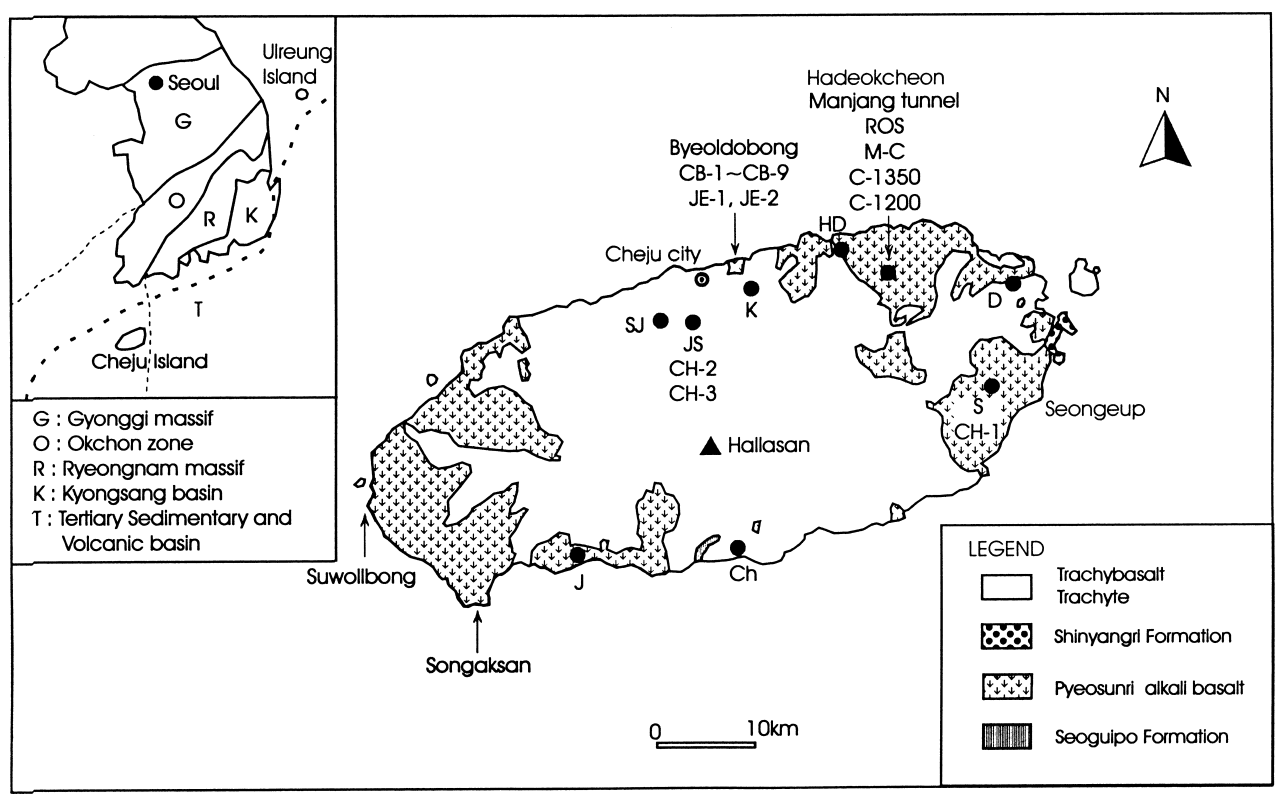

Fig. 1. Sampling sites of granitic rocks in the Cheju volcanic island. Geological map after Lee (1982). Drilling sites in which granite is encountered in the drilling core are included (Koh, 1997; Son, 1997; Yun et al., 1998). (K: Yeondong, ROS: Hadeokcheon, D: Jongdal, J: Jungmun, JS: Jeongshil, HD: Hamdeok, Ch: Cheonjiyeon, S: Seongeup, SJ: Shin-Cheju). CH-1, CH-2 and C-1200 indicate sample numbers.

Cenozoic volcanism including the Tertiary Cheju volcanism of the southeastern part of the Eurasian plate. In particular, to elucidate the Cheju volcanogenic processes, the magma has been proposed to be normal oceanic alkalic basalt magma (Lee, 1982), and the basement rock has been assumed to be continental and/or oceanic crust (Lee, 1982; Won et al., 1986; Min et al., 1988). The isolated Quaternary volcanic events in Cheju island represent intraplate hot spots (Lee, 1982; Won et al., 1986; Chough et al., 2000). Until recently, very little was known about the basement geology and the origin of alkali basaltic magma in the volcanic island.

As shown in Figs. 1 and 2, recently, several deep and hundreds of shallow holes drilled to exploit hot spring and groundwater have revealed that the volcanic rocks are present only above $c a$. $100 \mathrm{~m}$ below sea level and are underlain by a few hundreds of meter thick sedimentary rocks and unconsolidated sediments of the Plio-Pleistocene lying on the Cretaceous volcanic and granitic rocks
(Yun and Kim, 1984; Koh et al., 1982, 1993; Yoon et al., 1995b).

The purpose of this paper is to examine geochemical and isotopic characteristics and radiometric age and evolution of concealed granitic basement rocks beneath the Cheju volcanic island and to correlate the basement geology between the island and the Korean peninsula.

We report K-Ar and CHIME ages of granitic rocks from the drill cores and of granite xenoliths from the Byeoldobong pyroclastic deposits, and correlate chemical (REE), Nd-Sr isotopic compositions and model ages for granitic rocks in the petrochemical view point with that those of the Korean peninsula. K-Ar ages for alkali volcanic rocks were also included to discuss the evolution of the basement rock and alkali volcanic rocks.

\section{Geologic Setting}

In a tectonic sense, the Cheju Island is situated in the continental margin and belongs to the 


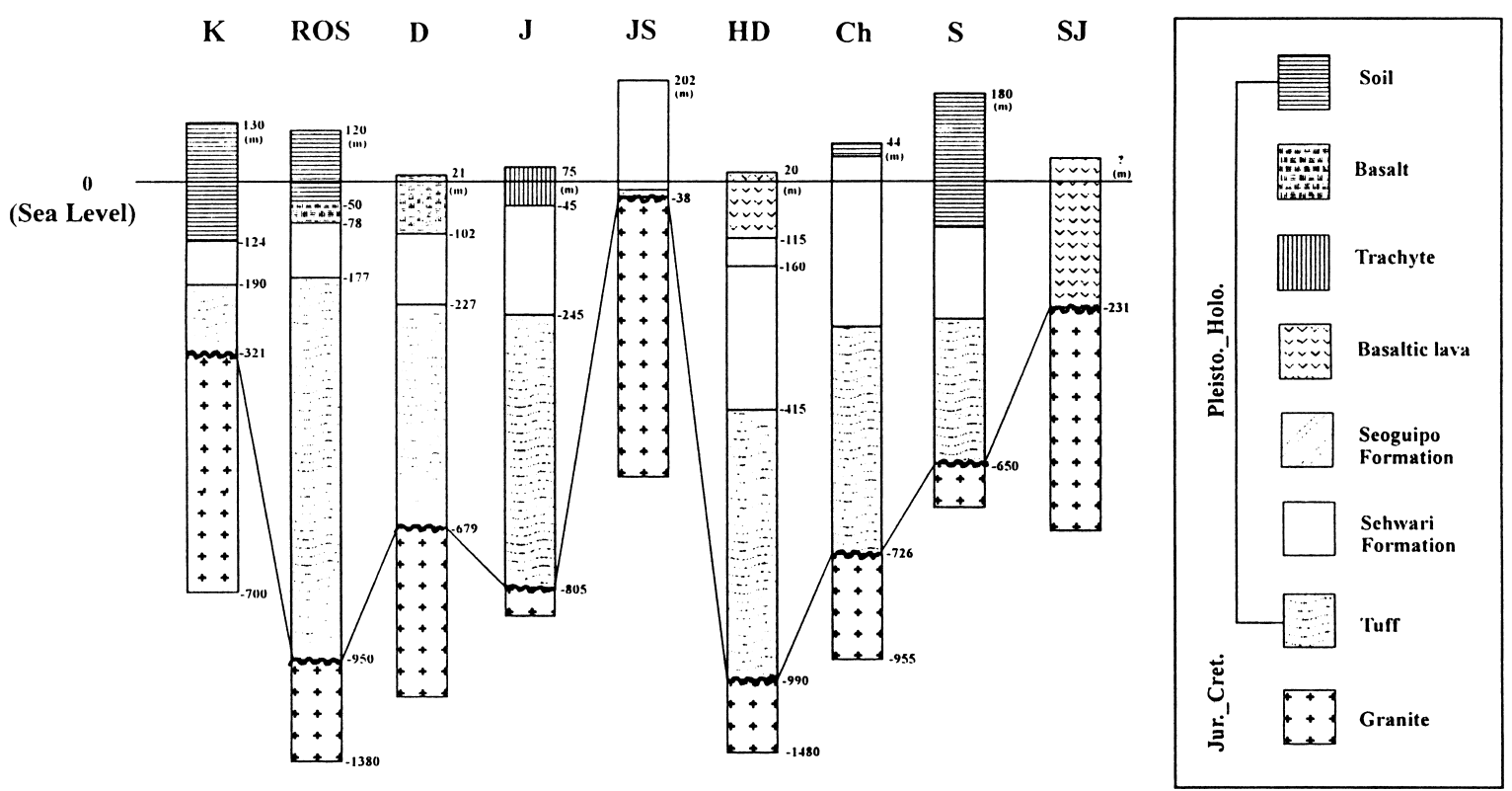

Fig. 2. Correlation of a tuff layer and granite in the drilling cores which are known as basement rocks in the Cheju volcanic island (Son, 1997; Koh, 1997; Yun et al., 1998). Abbreviations are the same as in Fig. 1.

Cenozoic alkali rock province (Lee, 1982; Kim et al., 1999). The volcanic island consists mainly of Cenozoic alkali basaltic lava flows, pyroclastics and marine fossiliferous sedimentary formations known as Seoguipo and Shinyangri Formations. Geological, geochemical and $\mathrm{Nd}-\mathrm{Sr}$ isotopical characteristics of these volcanic rocks have been reported in detail by previous researchers (Lee, 1982, 1989; Park and Kwon, 1993; Lee et al., 1994; Park et al., 1996; Kim et al., 1999).

The volcanic history of the Cheju island comprises the following three stages: (1) lava plateau stage (2) shield volcano stage and (3) scoria cinder cone stage (Lee, 1982). Based on the existing $\mathrm{K}-\mathrm{Ar}$ age data for the volcanic rocks (Appendix), the age spectrum of volcanic activity is found to be composed of three substages of 2.2 1.2 Ma, 1.0 0.8 Ma and 0.2 0.03 Ma (Fig. 3).

\section{Occurrence of basement rocks}

Granite xenoliths have been found at a few localities in Tertiary pyroclastic tuffaceous deposits, especially in the Byeoldobong area. Subangula granitic xenoliths of 5 to $20 \mathrm{~cm}$ in diameter are dominated by medium grained biotite granite, porphyritic hornblende-biotite granite along with a subordinate amount of two mica granite. The porphyritic hornblende-biotite granites have a small amount of prismatic alkali feldspar phenocrysts of 0.5 to $5 \mathrm{~cm}$ in length. The granite is correlated to the pre-Cretaceous muscovite granite in the southwestern area of the peninsula (Yun et al., 1998, 1999). Porphyritic hornblende-biotite granite contains quartz, microcline, plagioclase, hornblende, biotite with small amounts of magnetite, apatite, zircon, allanite and epidote. However rare granite gneiss fragments as well as granite fragments were also found in Tertiary tuffaceous formation of the Songacksan and Suwollbong areas (Son, 1997).

Based on the observations of cores from nine drilling sites except the Shin-Cheju area, a pyroclastic formation covers unconformably the granitic basement (Figs. 1 and 2) and is composed of volcanogenic sandstone and mudstone, trachytic welded tuff and tuff breccia. This volcanogenic formation can be correlated with the Yuchon group in the Kyoungsang sedimentary 


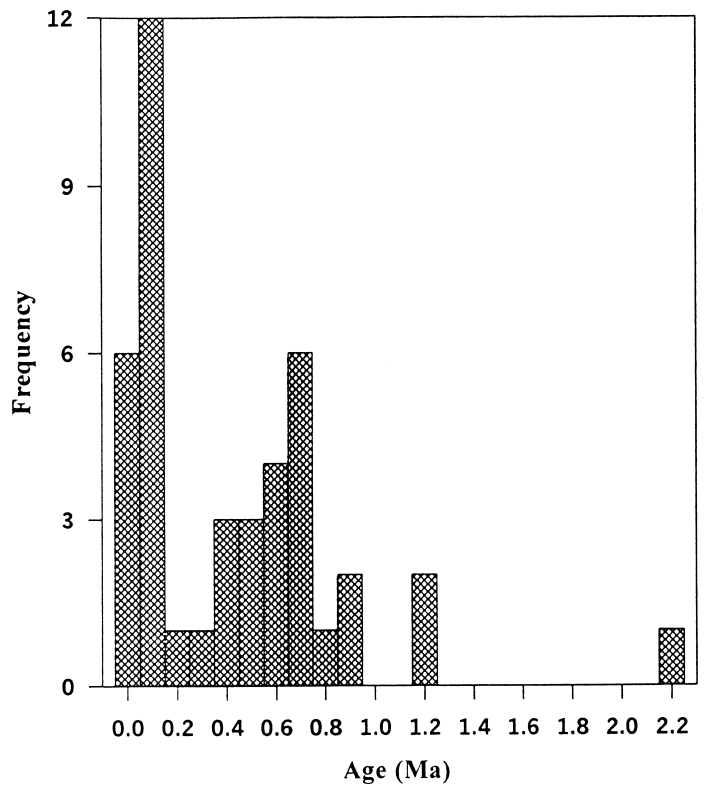

Fig. 3. Distribution of $K$-Ar ages for volcanic rocks from the Cheju volcanic island based on the data of Appendix.

basin in the southern part of the Korean peninsula (Koh, 1997). K-Ar ages of the granitic rocks from the Hadeokcheon and Manjang tunnel areas have been reported to be the same as those for the Cretaceous Bulguksa granite (Ahn et al., 1995; Lee, 1996).

A pink feldspar porphyritic granite in the Hadeokcheon area is composed mainly of quartz, plagioclase, alkali feldspar, biotite and a small amount of apatite. The granite is characterized by a micrographic texture, normally zoned plagioclase and a miarolitic texture which are commonly observed in the graphic granite called Masanite in the Kyoungsang basin.

Porphyritic hornblende-biotite granite (Sample No. CH-1) with feldspar phenocrysts sampled at $-650 \mathrm{~m}$ level of the drilling core in the Seongeup (Site No. S) and $-38 \mathrm{~m}$ level of the drilling core in the Jeongshil (HD) show a quite lithologic character similar to the porphyritic hornblende-biotite granite xenoliths in the Byeoldobong area, suggesting that the granitic xenoliths from the Byeoldobong were originated from the former rock in the Cheju island.
The above facts suggest that the basement rock of the Cheju volcanic island consist mainly of granitic plutons of Jurassic and Cretaceous ages and Precambrian gneisses, which are typical continental crustal materials found in the peninsula which is particularly analogous to the rock types of basement in the Okchon zone.

\section{Analytical Procedures}

The granitic rock samples were collected from the pyroclastic deposits in the Byeoldobong area and the drilling cores in the Hadeokcheon area. These were crushed to powder for chemical and isotopic analyses.

Major (quoted as weight percent oxides), trace (ppm element up to 5000 ppm) and REE (subppm level) element concentrations were determined on an inductively coupled plasma mass spectrometer (ICP-MS) at Kings College, University of London, England.

$\mathrm{K}-\mathrm{Ar}$ age dating was carried out by the isotopic dilution method using ${ }^{38} \mathrm{Ar}$ spike on a VG 5400 mass spectrometer at Institute for Study of the Earth's Interior, Okayama University, Japan. $\mathrm{K}$-concentrations were measured on an atomic absorption spectrophotometer with $2 \%$ analytical error at Nagoya University, Japan.

Zircon and allanite grains were selected in a thin section to analyze $\mathrm{ThO}_{2}, \mathrm{UO}_{2}$ and $\mathrm{PbO}$ contents on a JXA-733 electron microprobe at Nagoya University. The analytical procedure and CHIME age calculation were those of Suzuki et al. (1994). The instrument conditions were $15 \mathrm{kV}$ accelerating voltage, $0.25 \mu \mathrm{A}$ probe current on a Faraday cage and $5 \mu \mathrm{m}$ probe diameter. X-ray intensities are integrated for 300 seconds by means of 5 times cyclic stepping of spectrometer on individual peak and background positions. X-ray intensity data were converted into concentrations by the method of Bence and Albee (1968). The standards were used by Smellie et al. (1978) for Th and U, and synthesized glass (10.18 wt.\% PbO, Suzuki and Adachi, 1998) for $\mathrm{Pb}$. The detection limits $1 \sigma$ confidence level are 0.007, 0.01 and $0.003 \mathrm{wt} . \%$ for $\mathrm{ThO}_{2}, \mathrm{UO}_{2}$ and $\mathrm{PbO}$, respectively. The relative 
Table 1. CHIME and K-Ar ages of granitic rocks from the Cheju volcanic island

\begin{tabular}{|c|c|c|c|c|}
\hline Method & Rock type & Specimen & Age (Ma) & Remark \\
\hline CHIME & $\begin{array}{l}\text { Porphyritic hornblende-biotite granite } \\
\text { from the pyroclastic formation of the Beoldobong area }\end{array}$ & zircon & $173 \pm 31$ & this study \\
\hline $\mathrm{K}-\mathrm{Ar}$ & $\begin{array}{l}\text { Biotite granite xenolith from the pyroclastic formation } \\
\text { of the Beoldobong area }\end{array}$ & biotite & $172.4 \pm 5.2$ & this study \\
\hline $\mathrm{K}-\mathrm{Ar}$ & Feldspar granite from the Hadeokcheon area & alkali-feldspar & $58.1 \pm 1.4$ & Ahn et al. (1995) \\
\hline $\mathrm{K}-\mathrm{Ar}$ & Granite from the Deokcheon (Manjang tunnel) area & whole rock & $66.4 \pm 1.7$ & Lee (1996) \\
\hline
\end{tabular}

errors are $c a .30 \%$ for 0.01 wt. $\%$ of the $\mathrm{PbO}$ concentration, $6 \%$ for $0.3 \mathrm{wt} . \%$ of $\mathrm{UO}_{2}$ concentration and $1 \%$ for $10 \mathrm{wt} . \%$ of $\mathrm{ThO}_{2}$ concentration.

For $\mathrm{Sr}$ and $\mathrm{Nd}$ isotopic analyses, the conventional standard cation exchange technique using $\mathrm{HCl}$ elutant (Dosso and Murthy, 1980) was used to separate $\mathrm{Sr}$ and REE (Nd). $\alpha$-hydroxy isobutyric acid (HIBA) was used to separated $\mathrm{Nd}$ from other REEs. Isotopic ratios were measured on a VG sector thermal ionization mass spectrometer at Nagoya University. ${ }^{143} \mathrm{Nd} /{ }^{144} \mathrm{Nd}$ and ${ }^{87} \mathrm{Sr} /{ }^{86} \mathrm{Sr}$ ratios were normalized to ${ }^{146} \mathrm{Nd} /{ }^{144} \mathrm{Nd}=0.7219$ and ${ }^{86} \mathrm{Sr} /{ }^{88} \mathrm{Sr}=0.1194$, respectively. Analysis of standard NBS987 yields a mean ${ }^{87} \mathrm{Sr} /{ }^{86} \mathrm{Sr}$ value of $0.7102530 \pm(10)$.

${ }^{143} \mathrm{Nd} /{ }^{144} \mathrm{Nd}$ measurements of standard LaJolla and JNdi yielded $0.5118291 \pm(9)$ and $0.5121025 \pm(8)$, respectively. Within-run precision was always insignificant compared to reproducibility of the reference materials. The $\varepsilon_{\mathrm{Sr}}$ and $\varepsilon_{\mathrm{Nd}}$ values were calculated using the model parameters such as ${ }^{87} \mathrm{Sr} /{ }^{86} \mathrm{Sr}=0.7045,{ }^{87} \mathrm{Rb} /$ ${ }^{86} \mathrm{Sr}=0.0827,{ }^{143} \mathrm{Nd} /{ }^{144} \mathrm{Nd}=0.51264$ and ${ }^{147} \mathrm{Sm} /$ ${ }^{144} \mathrm{Nd}=0.1967$ (Jacobsen and Wasserburg, 1980; Wasserburg et al., 1981). Depleted mantle parameters for $\mathrm{T}^{\mathrm{Nd}}{ }_{\mathrm{DM}}$ model age calculation were ${ }^{143} \mathrm{Nd} /$ ${ }^{144} \mathrm{Nd}=0.513114$ and ${ }^{147} \mathrm{Sm} /{ }^{144} \mathrm{Nd}=0.222$ (Michard et al., 1985).

\section{RAdiometric Ages of The Granitic Rocks}

Only two K-Ar ages for the granitic rock specimens from drilling cores in the Hadeokcheon and Manjang tunnel areas have been reported to be $58.14 \pm 1.4 \mathrm{Ma}$ (Ahn et al., 1995) and $66.4 \pm 1.7$ Ma (Lee, 1996). On the basis of these ages and lithology of the granitic rocks, previous researchers (Ahn et al., 1995; Lee, 1996; Yun et al., 1999) were led to conclude that the basement rock of the Cheju volcanic island comprises Cretaceous granitic rocks which are the same as those scatteredly distributed in the Kyoungsang sedimentary basin in the south of the Korean peninsula.

\section{$K$-Ar age}

A K-Ar biotite age for a porphyritic hornblende-biotite granite xenolith is obtained to be $172.4 \pm 5.2 \mathrm{Ma}$, corresponding to a Jurassic age (Table 1). This is the first finding of the Jurassic granite and gives constraint for events of plutonism on the island. Particulary in the Jurassic, voluminous syntectonic granitic plutons known as the Daebo granite were widely emplaced during the Daebo orogeny along with the Sinian direction in the Precambrian basement of the peninsula.

Nine alkali volcanic rock samples from the island were taken for radiometric dating. $\mathrm{K}$-Ar ages of the volcanic rocks range from 0.06 to $0.45 \mathrm{Ma}$, corresponding to the Pleistocene (Table 2). Compilation of the exsisting $43 \mathrm{~K}$-Ar dating results is listed in Appendix and shown Fig. 4. The radiometric age spectrum of the volcanic rocks covers a wide range from 2.2 to $0.03 \mathrm{Ma}$ with periodic intensities of volcanic activities as shown in Fig. 3. The age gap between the plutonism and volcanism in the island is about $60 \mathrm{Ma}$.

\section{CHIME age}

Zircon, monazite and allanite minerals in granitic rocks have their high blocking temperatures 
Table 2. K-Ar ages of alkali volcanic rocks and biotite granite from the Cheju volcanic island, Korea

\begin{tabular}{llcrrrr}
\hline Sample No. & Rock type & $\begin{array}{c}\mathrm{K} \\
(\mathrm{wt} \%)\end{array}$ & $\begin{array}{c}{ }^{36} \mathrm{Ar} \\
\left(10^{-10} \mathrm{cc} / \mathrm{g}\right)\end{array}$ & $\begin{array}{c}{ }^{40} \mathrm{Ar}(\mathrm{rad}) \\
\left(10^{-8} \mathrm{c} \mathrm{c} / \mathrm{g}\right)\end{array}$ & $\begin{array}{c}\mathrm{K}-\mathrm{Ar} \text { age } \\
(\mathrm{Ma})\end{array}$ & $\begin{array}{c}\mathrm{Atm} .{ }^{40} \mathrm{Ar} \\
(\%)\end{array}$ \\
\hline JB7 & Basaltic trachyandesite & 1.84 & $6.58 \pm 0.11$ & $0.89 \pm 0.03$ & $0.13 \pm 0.01$ & 95.6 \\
JB18 & Basalt (Hawaiite) & 1.13 & $4.39 \pm 0.09$ & $0.40 \pm 0.02$ & $0.09 \pm 0.01$ & 96.9 \\
JB26 & Basalt (Hawaiite) & 1.09 & $4.18 \pm 0.08$ & $1.92 \pm 0.05$ & $0.45 \pm 0.01$ & 86.5 \\
JBY4 & Trachybasalt & 1.57 & $4.96 \pm 0.97$ & $1.87 \pm 0.05$ & $0.31 \pm 0.01$ & 88.6 \\
JT19 & Basalt & 1.10 & $3.15 \pm 0.07$ & $0.35 \pm 0.02$ & $0.083 \pm 0.004$ & 96.3 \\
CY8 & Trachybasalt & 1.19 & $4.17 \pm 0.08$ & $1.88 \pm 0.05$ & $0.41 \pm 0.02$ & 93.3 \\
JS 14 & Basalt & 0.98 & $3.88 \pm 0.08$ & $0.79 \pm 0.03$ & $0.21 \pm 0.01$ & 93.3 \\
JSK1 & Trachybasalt & 1.44 & $7.51 \pm 0.11$ & $0.31 \pm 0.03$ & $0.06 \pm 0.01$ & 98.5 \\
JE2 & Biotite granite (Biotite) & 0.90 & $40.86 \pm 0.66$ & $4844.28 \pm 48.88$ & $172.36 \pm 5.20$ & 2.4 \\
\hline
\end{tabular}

${ }^{40} \mathrm{Ar}$ (rad) indicates radiogenic argon.

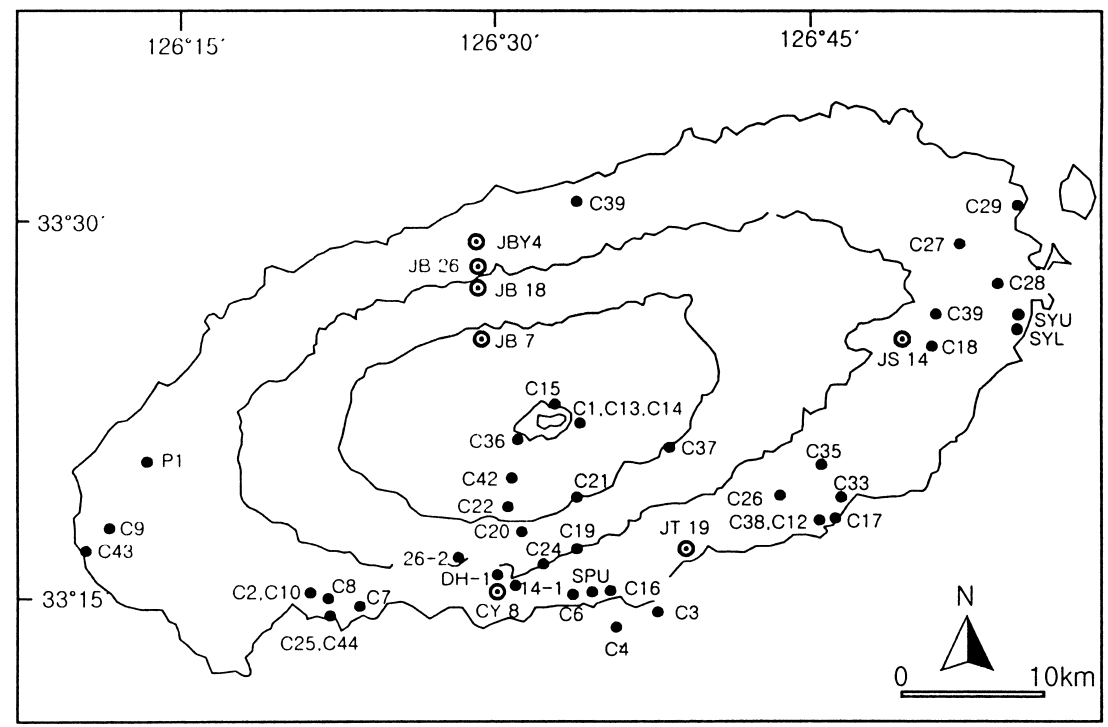

Fig. 4. Location map of radiometric ages of volcanic rocks in the Cheju volcanic island (Lee et al., 1994; Yoon et al., 1995a; KIGAM, 1995; Kim et al., 1999).

for $\mathrm{Pb}$ and high concentrations of $\mathrm{Th}$ and $\mathrm{U}$ (Scharer et al., 1984; Suzuki et al., 1994, 1996; Takeuchi and Suzuki, 2000). For this reason, an isochron age of the CHIME method is used as one suitable tool for radiometric dating (Suzuki and Adachi, 1991; Suzuki et al., 1994). The porphyritic hornblende-biotite granite xenolith from the Byeoldobong pyroclastic formation have rare zircon, monazite and allanite grains. Zircon grains from the granitic rocks are euhedral and extremely small with about $0.2 \mu \mathrm{m}$ across. Relatively clear crystals were selected for $\mathrm{U}-\mathrm{Pb}$ analyses.

The $\mathrm{ThO}_{2}, \mathrm{UO}_{2}$ and $\mathrm{PbO}$ analytical results for zircon and allanite with apparent ages and calculated $\mathrm{ThO}_{2}$, * or $\mathrm{UO}_{2} *$ (Suzuki and Adachi, 1991) are listed in Table 3.

Zircon A total of twenty nine spots on six zircon grains from porphyritic horblende-biotite granite (Sample No. CB-2) were analyzed. The $\mathrm{ThO}_{2}$ and $\mathrm{UO}_{2}$ contents range from 0.004 to $0.281 \mathrm{wt} . \%$ and from 0.015 to 0.583 wt. $\%$, respectively. Zircons have a relatively low content of $\mathrm{PbO}$ and a large 
$\mathrm{PbO}$ (wt. \%)
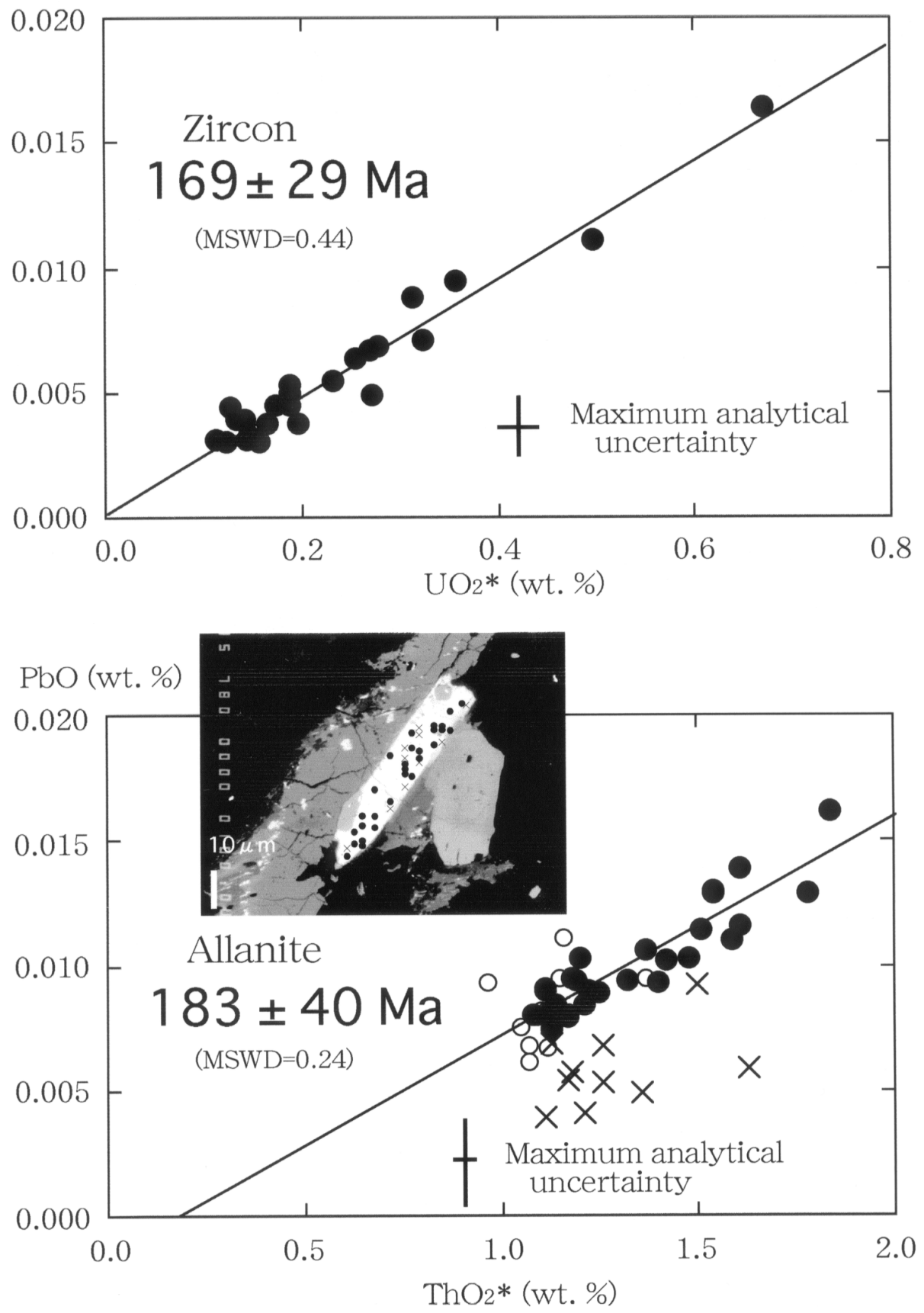

Fig. 5. Plots of $\mathrm{PbO}$ vs. $\mathrm{UO}_{2}$ * for zircon and $\mathrm{PbO}$ vs. $\mathrm{ThO}_{2}$ * for allanite in the granite (Sample No. CB-2) from the Cheju volcanic island, Korea. Data designated by open circle are from another allanite grain which is not shown in this microphotography. Data expressed by cross marks confirmed that most analytical spots are closely related to cracks in allanite grain. $\mathrm{UO}_{2} *$ : sum of the measured $\mathrm{UO}_{2}$ and $\mathrm{UO}_{2}$ equivalent of the measured ThO $\mathrm{O}_{2}$ for zircon. $\mathrm{ThO}_{2}{ }^{*}$ : sum of the measured $\mathrm{ThO}_{2}$ and $\mathrm{ThO}_{2}$ equivalent of the measured $\mathrm{UO}_{2}$ for allanite. Error bars in the figure represent $2 \sigma$ analytical uncertainty, and errors given to the age of $2 \sigma$. MSWD: mean square of weighted deviates. 
Table 3. Electron microprobe analyses of $\mathrm{UO}_{2}, \mathrm{ThO}_{2}$ and $\mathrm{PbO}$ of zircon and allanite grains from porphyritic horblende-biotite granite (Sample No. CB-2) in the Byeoldobong volcano pyroclastic sediments, Cheju volcanic island

\begin{tabular}{|c|c|c|c|c|c|}
\hline & $\mathrm{ThO}_{2}$ (wt.\%) & $\mathrm{UO}_{2}$ (wt. $\%$ ) & $\mathrm{PbO}$ (wt.\%) & Age (Ma) & $\mathrm{UO}_{2} *(\mathrm{wt} . \%)$ \\
\hline Z01-01 & 0.031 & 0.164 & 0.0045 & 192 & 0.173 \\
\hline Z01-02 & 0.100 & 0.223 & 0.0064 & 186 & 0.254 \\
\hline Z01-03 & 0.060 & 0.213 & 0.0055 & 176 & 0.232 \\
\hline Z01-04 & 0.159 & 0.448 & 0.0111 & 165 & 0.498 \\
\hline Z01-05 & 0.281 & 0.583 & 0.0164 & 181 & 0.670 \\
\hline Z02-01 & 0.017 & 0.139 & 0.0031 & 159 & 0.145 \\
\hline Z02-02 & 0.089 & 0.250 & 0.0069 & 184 & 0.278 \\
\hline $\mathrm{Z} 02-03$ & 0.050 & 0.181 & 0.0038 & 144 & 0.196 \\
\hline Z02-04 & 0.059 & 0.099 & -1.0000 & 0 & 0.000 \\
\hline Z02-05 & 0.057 & 0.130 & 0.0033 & 166 & 0.147 \\
\hline Z03-01 & 0.019 & 0.136 & 0.0039 & 204 & 0.141 \\
\hline Z03-02 & 0.092 & 0.295 & 0.0071 & 163 & 0.324 \\
\hline Z04-01 & 0.008 & 0.270 & 0.0049 & 134 & 0.272 \\
\hline Z04-02 & 0.019 & 0.308 & 0.0088 & 207 & 0.313 \\
\hline Z04-03 & 0.010 & 0.266 & 0.0067 & 184 & 0.269 \\
\hline Z04-04 & 0.017 & 0.127 & 0.0039 & 217 & 0.133 \\
\hline Z04-05 & 0.023 & 0.350 & 0.0095 & 197 & 0.357 \\
\hline Z05-01 & 0.008 & 0.057 & -1.0000 & 0 & 0.000 \\
\hline Z05-02 & 0.004 & 0.015 & -1.0000 & 0 & 0.000 \\
\hline Z05-03 & 0.004 & 0.051 & -1.0000 & 0 & 0.000 \\
\hline Z05-04 & 0.016 & 0.097 & -1.0000 & 0 & 0.000 \\
\hline Z06-01 & 0.009 & 0.110 & 0.0031 & 204 & 0.112 \\
\hline Z06-02 & 0.052 & 0.112 & 0.0044 & 252 & 0.128 \\
\hline Z06-03 & 0.075 & 0.165 & 0.0050 & 197 & 0.188 \\
\hline Z06-04 & 0.027 & 0.148 & 0.0030 & 142 & 0.157 \\
\hline Z06-05 & 0.008 & 0.122 & 0.0030 & 179 & 0.124 \\
\hline Z06-06 & 0.029 & 0.179 & 0.0053 & 208 & 0.188 \\
\hline Z06-07 & 0.017 & 0.183 & 0.0045 & 177 & 0.188 \\
\hline Z06-08 & 0.026 & 0.158 & 0.0038 & 170 & 0.166 \\
\hline
\end{tabular}

range from less than detection limit to 0.0164 wt.\%. Therefore, apparent ages, to some extent, were obtained to be a wide range from 134 to 252 Ma (Table 3). However, all zircon analytical data lie on a line on the $\mathrm{PbO}$ versus $\mathrm{UO}_{2}$ * diagram, and give a well defined isochron age of $169 \pm 29 \mathrm{Ma}(\mathrm{MSWD}=0.44)$ (Fig. 5).

Allanite Forty nine spots on three allanite grains from the granite (Sample No. CB-2) were analyzed. The $\mathrm{ThO}_{2}$ content ranges from 0.897 to $1.705 \mathrm{wt} \%$, and the $\mathrm{UO}_{2}$ content from 0.009 to $0.082 \mathrm{wt} . \%$ and the $\mathrm{PbO}$ content from 0.0039 to 0.0162 wt. \%. On the $\mathrm{PbO}-\mathrm{ThO}_{2}{ }^{*}$ diagram, the data of thirty eight analytical spots define an isochron age of $183 \pm 40 \mathrm{Ma}(\mathrm{MSWD}=0.24)$ (Fig. 5). Some data designated by cross marks on the allanite grain and on $\mathrm{PbO}-\mathrm{ThO}_{2}$ * diagram were plotted scatteredly as shown in Fig. 5. The lead loss of allanite grain during the hydrothermal alteration processes can be considered. These scattered analytical spots located in the vicinity of cracks in the allanite grain can cause more easily lead loss during the alteration processes. Therefore, this kind of EPMA analytical data on the allanite grains failed to give an isochron.

Even though above CHIME ages from two different minerals have a wide range, the ages are overlapped within analytical errors, suggesting age of Jurassic. These CHIME ages coincide with the $\mathrm{K}$-Ar age of $172.4 \pm 5.2 \mathrm{Ma}$. This new radiometric age provides us an important information for the evolution of the basement in the Cheju volcanic island. 
Table 3. (continued)

\begin{tabular}{|c|c|c|c|c|c|}
\hline & $\mathrm{ThO}_{2}(\mathrm{wt} . \%)$ & $\mathrm{UO}_{2}(\mathrm{wt} . \%)$ & $\mathrm{PbO}$ (wt.\%) & Age (Ma) & $\mathrm{ThO}_{2} *$ \\
\hline A01-01 & 1.130 & 0.009 & 0.0095 & 195 & 1.15 \\
\hline A01-03 & 1.010 & 0.019 & 0.0068 & 150 & 1.07 \\
\hline A01-04 & 1.330 & 0.013 & 0.0095 & 164 & 1.37 \\
\hline A01-05 & 1.030 & 0.018 & 0.0079 & 171 & 1.09 \\
\hline A01-06 & 0.956 & 0.035 & 0.0061 & 135 & 1.07 \\
\hline A02-01 & 1.030 & 0.020 & 0.0079 & 171 & 1.09 \\
\hline A02-02 & 1.000 & 0.016 & 0.0075 & 168 & 1.05 \\
\hline A02-03 & 0.897 & 0.021 & 0.0093 & 228 & 0.97 \\
\hline A02-04 & 1.020 & 0.030 & 0.0067 & 142 & 1.12 \\
\hline A02-05 & 1.040 & 0.019 & 0.0082 & 176 & 1.10 \\
\hline A03-01 & 1.450 & 0.056 & 0.0059 & 86 & 1.63 \\
\hline A03-02 & 1.413 & 0.055 & 0.0110 & 164 & 1.59 \\
\hline A03-03 & 1.423 & 0.037 & 0.0129 & 198 & 1.54 \\
\hline A03-04 & 1.010 & 0.061 & 0.0084 & 165 & 1.21 \\
\hline A03-05 & 1.043 & 0.064 & 0.0089 & 168 & 1.25 \\
\hline A03-06 & 1.511 & 0.031 & 0.0116 & 170 & 1.61 \\
\hline A03-07 & 1.142 & 0.036 & 0.0068 & 128 & 1.26 \\
\hline A03-08 & 1.705 & 0.043 & 0.0162 & 208 & 1.84 \\
\hline A03-09 & 1.140 & 0.029 & 0.0089 & 171 & 1.23 \\
\hline A03-10 & 1.294 & 0.033 & 0.0093 & 157 & 1.40 \\
\hline A03-11 & 1.026 & 0.026 & 0.0039 & 83 & 1.11 \\
\hline A03-12 & 1.081 & 0.028 & 0.0054 & 109 & 1.17 \\
\hline A03-13 & 1.038 & 0.032 & 0.0084 & 174 & 1.14 \\
\hline A03-14 & 1.075 & 0.031 & 0.0080 & 161 & 1.17 \\
\hline A03-15 & 1.075 & 0.033 & 0.0057 & 114 & 1.18 \\
\hline A03-16 & 1.041 & 0.025 & 0.0081 & 171 & 1.12 \\
\hline A03-17 & 1.096 & 0.031 & 0.0103 & 204 & 1.20 \\
\hline A03-18 & 1.001 & 0.035 & 0.0090 & 191 & 1.11 \\
\hline A03-19 & 1.084 & 0.038 & 0.0041 & 80 & 1.21 \\
\hline A03-20 & 1.043 & 0.027 & 0.0069 & 145 & 1.13 \\
\hline A03-21 & 1.006 & 0.032 & 0.0091 & 194 & 1.11 \\
\hline A03-22 & 1.649 & 0.039 & 0.0129 & 172 & 1.78 \\
\hline A03-23 & 1.097 & 0.029 & 0.0094 & 187 & 1.19 \\
\hline A03-24 & 1.161 & 0.031 & 0.0053 & 99 & 1.26 \\
\hline A03-25 & 1.196 & 0.038 & 0.0094 & 169 & 1.32 \\
\hline A03-26 & 1.362 & 0.047 & 0.0114 & 178 & 1.51 \\
\hline A03-27 & 1.371 & 0.042 & 0.0092 & 145 & 1.50 \\
\hline A03-28 & 1.113 & 0.033 & 0.0090 & 175 & 1.22 \\
\hline A03-29 & 1.089 & 0.025 & 0.0079 & 160 & 1.17 \\
\hline A03-30 & 1.326 & 0.047 & 0.0103 & 165 & 1.48 \\
\hline A03-31 & 1.274 & 0.084 & 0.0130 & 199 & 1.54 \\
\hline A03-32 & 1.061 & 0.023 & 0.0074 & 154 & 1.13 \\
\hline A03-33 & 1.274 & 0.030 & 0.0106 & 183 & 1.37 \\
\hline A03-34 & 1.348 & 0.082 & 0.0139 & 204 & 1.61 \\
\hline A03-35 & 1.306 & 0.035 & 0.0102 & 170 & 1.42 \\
\hline A03-36 & 1.006 & 0.024 & 0.0080 & 175 & 1.08 \\
\hline A03-37 & 1.238 & 0.038 & 0.0049 & 85 & 1.36 \\
\hline A03-38 & 1.072 & 0.033 & 0.0095 & 191 & 1.18 \\
\hline
\end{tabular}

Z: zircon, A: allanite, -1: less than detection limit.

$\mathrm{UO}_{2}{ }^{*}$ : Sum of the measured $\mathrm{UO}_{2}$ and $\mathrm{UO}_{2}$ equivalent of the measured $\mathrm{ThO}_{2}$ for zircons.

$\mathrm{ThO}_{2}$ *: Sum of the measured $\mathrm{ThO}_{2}$ and $\mathrm{ThO}_{2}$ equivalent of the measured $\mathrm{UO}_{2}$ for allanites. 

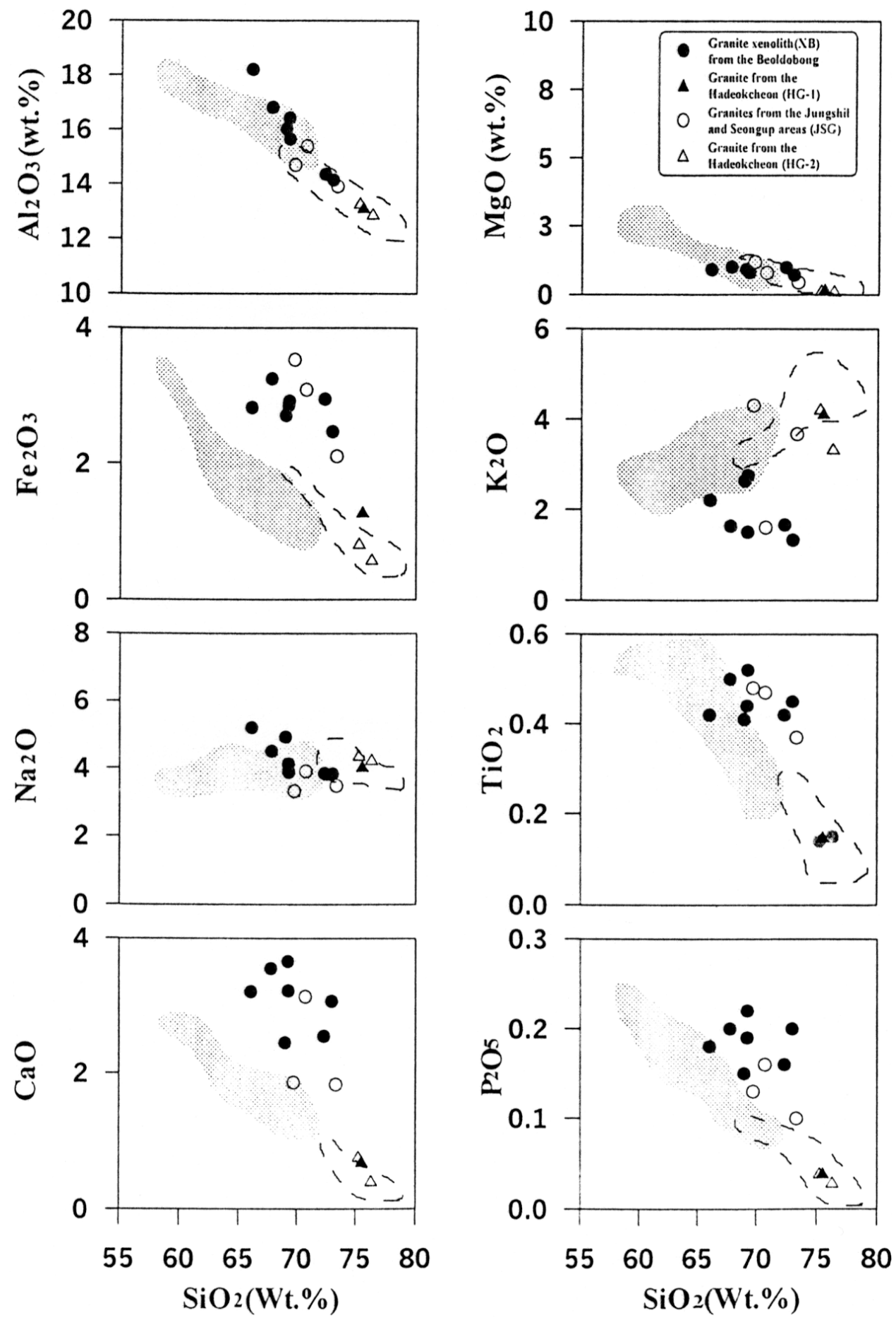

Fig. 6. Plot of major oxides vs. $\mathrm{SiO}_{2}$ for granitic rocks from the Cheju volcanic island. The dashed and shaded fields are the Bulguksa and Daebo granites, respectively, in South Korea (Kim et al., 1996). XB: granite xenolith from the Beoldobong area (this study), HG-1: Granite from the Hadeokcheon area (this study), JSG; Granite from the Jungshil and Seongeup area (this study), Granite from the Hadeokcheon area (Ahn et al., 1995; Yun et al., 1998). 


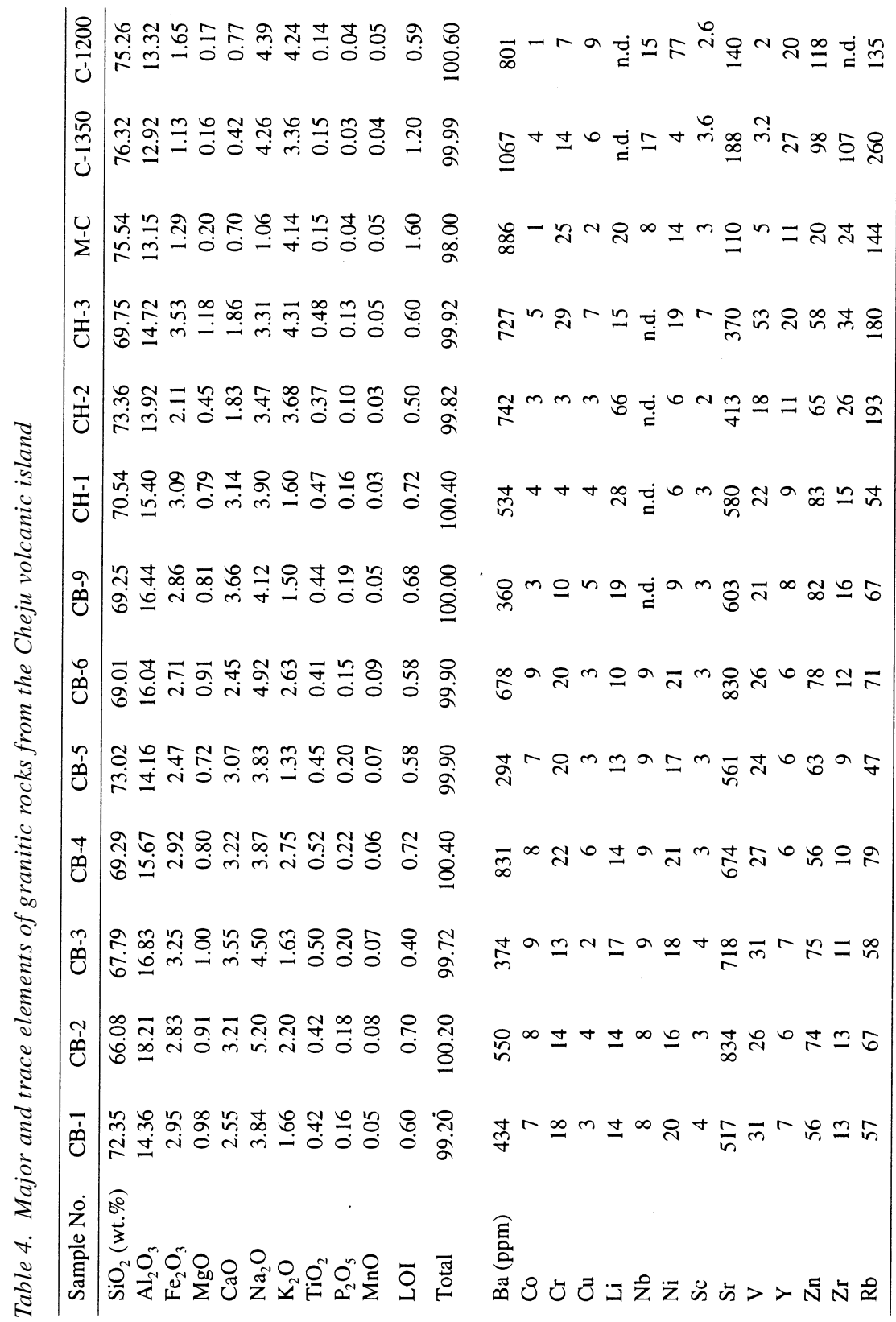




\section{GeOCHEMistry OF THE GRANITIC RoCKS}

Detailed petrographic descriptions of granite xenoliths and some drilled core samples were given by Ahn et al. (1995) and Yun et al. (1999). Based on concentrations of major elements including $\mathrm{SiO}_{2}, \mathrm{Al}_{2} \mathrm{O}_{3}, \mathrm{CaO}, \mathrm{MgO}, \mathrm{Na}_{2} \mathrm{O}, \mathrm{K}_{2} \mathrm{O}$ and $\mathrm{P}_{2} \mathrm{O}_{5}$, granitic rocks from the Cheju island are grouped into two groups: a high $\mathrm{SiO}_{2}$-low oxides and vice versa. In terms of silicate and oxides, $\mathrm{Al}_{2} \mathrm{O}_{3}$, $\mathrm{Fe}_{2} \mathrm{O}_{3}, \mathrm{CaO}, \mathrm{MgO}, \mathrm{TiO}_{2}$ and $\mathrm{P}_{2} \mathrm{O}_{5}$ show a negative trend. However, $\mathrm{K}_{2} \mathrm{O}$ shows a reverse trend.
These trends are characterized by Mesozoic granites such as Daebo and Bulguksa granites in the peninsula (Fig. 6, Table 4). The $\mathrm{SiO}_{2}$ content of the Bulguksa granite (avg. 74.58\%) is higher than those of the Daebo granite (avg. 68.12\%) (Kim, 1992; Hong, 1987). Granitic rocks from the Hadeokcheon drilling core (Sample Nos. M-C, C1350 and $\mathrm{C}-1200$ ) have high $\mathrm{SiO}_{2}$ contents ranging from 75.26 to $76.32 \mathrm{wt} \%$, similar to those of the Cretaceous Bulguksa granite $\left(\mathrm{SiO}_{2}=\right.$ 67.03 79.43, Kim, 1992). On the other hand, several granitic xenoliths from the Byeoldobong area
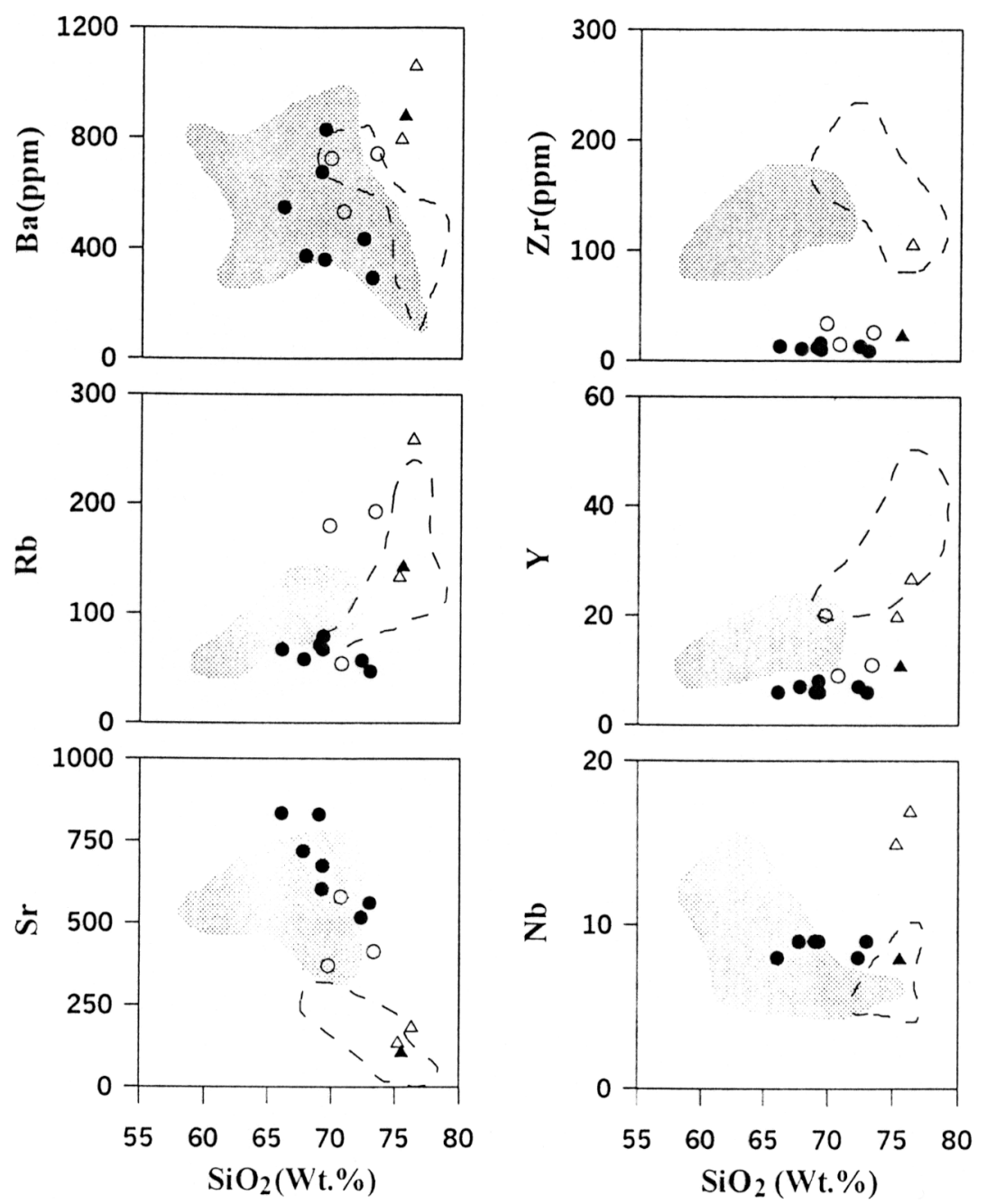

Fig. 7. Relationship between $\mathrm{SiO}_{2}$ and trace elements for granitic rocks from the Cheju volcanic island. Symbols are the same as in Fig. 6. 
Old continental basement in Cheju volcanic Island, South Korea

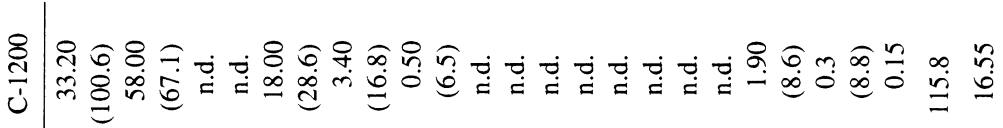

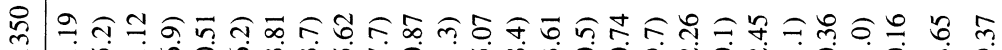

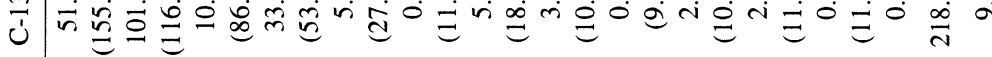

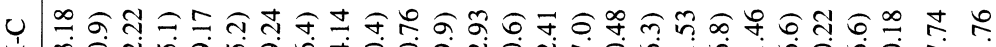

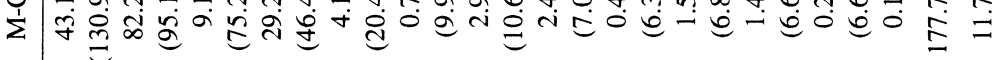

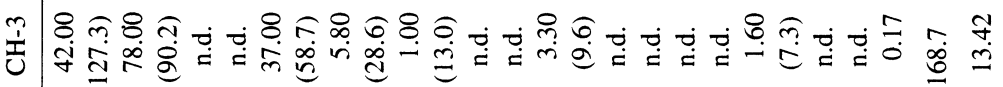

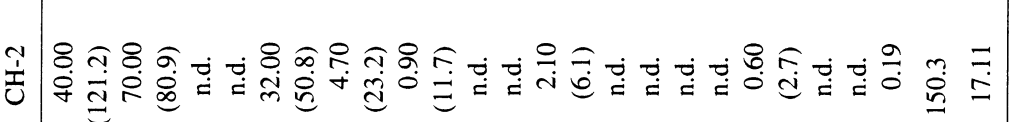

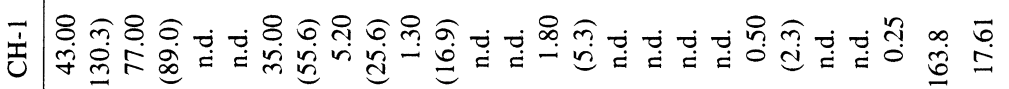

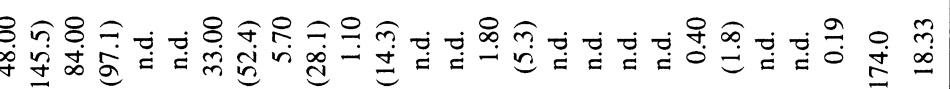

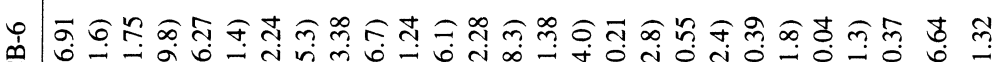

น กำต

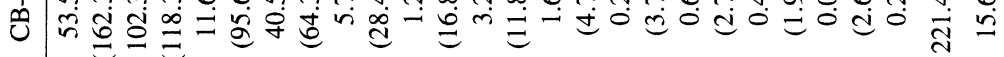

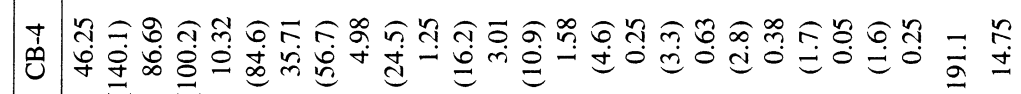

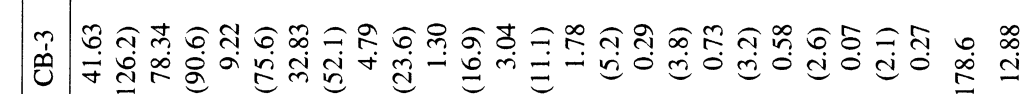

㺼

-

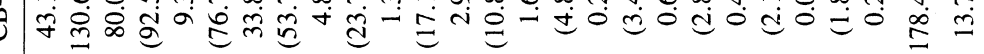

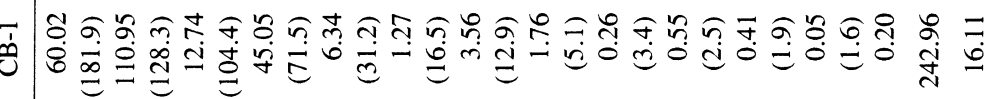

is

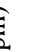

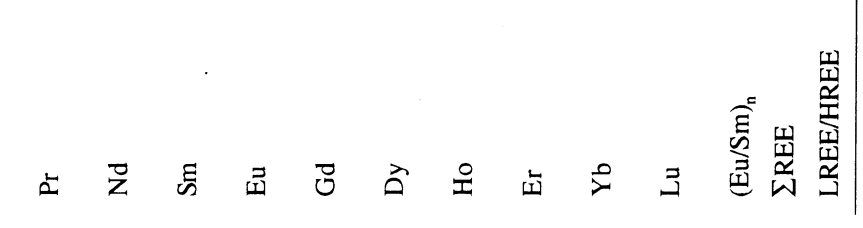


and two drilling core samples (Sample Nos. JS and $S$ ) from the Jeongshil and Seongeup areas have rather low $\mathrm{SiO}_{2}$ contents ranging from 66.08 to $73.36 \mathrm{wt} \%$. These are in a compositional range of the Jurassic Daebo granite $\left(\mathrm{SiO}_{2}=55.30 \sim 75.74\right.$, Kim, 1992). Compared to Mesozoic granitoids, the granite xenoliths relatively scatter in trace element contents (Fig. 7). The Sr contents of these granitic rocks is $370 \sim 834 \mathrm{ppm}$. It is compared with 174 681 ppm of $\mathrm{Sr}$ in the Daebo granite not with the Bulguksa granite of 6 197 ppm (Kim, 1992). In general, granitic rocks in the Cheju island have peraluminous and calc alkalic characteristics which are commonly shown by Mesozoic granitic rocks in the peninsula.

Total concentrations of REE range from 115.8 to $242.9 \mathrm{ppm}$ (Table 5). LREE/HREE ratios are 9.4 16.6 and show a relative enrichment in LREE. REE patterns of granitic rocks from the Byeoldobong, Joengshil and Seongeup areas resemble those of the Jurassic Daebo granite with HREE depletion and weak or lacking Eu anomaly, suggesting a deep seated crustal origin of the granitic magma. In addition, the Beoldobong granite xenoliths and the Hadeokcheon granite core samples show a relatively low $(\mathrm{Eu} / \mathrm{Sm})_{\mathrm{n}}$ value of $0.15 \sim 0.37$. Whereas, granitic rocks from the Hadeokcheon and Manjang tunnel areas have distinct Eu negative anomalies and also have REE patterns concordant to those of the Cretaceous Bulguksa granite (Fig. 8). As shown in Fig. 8, the Cretaceous Bulguksa granites have less depleted

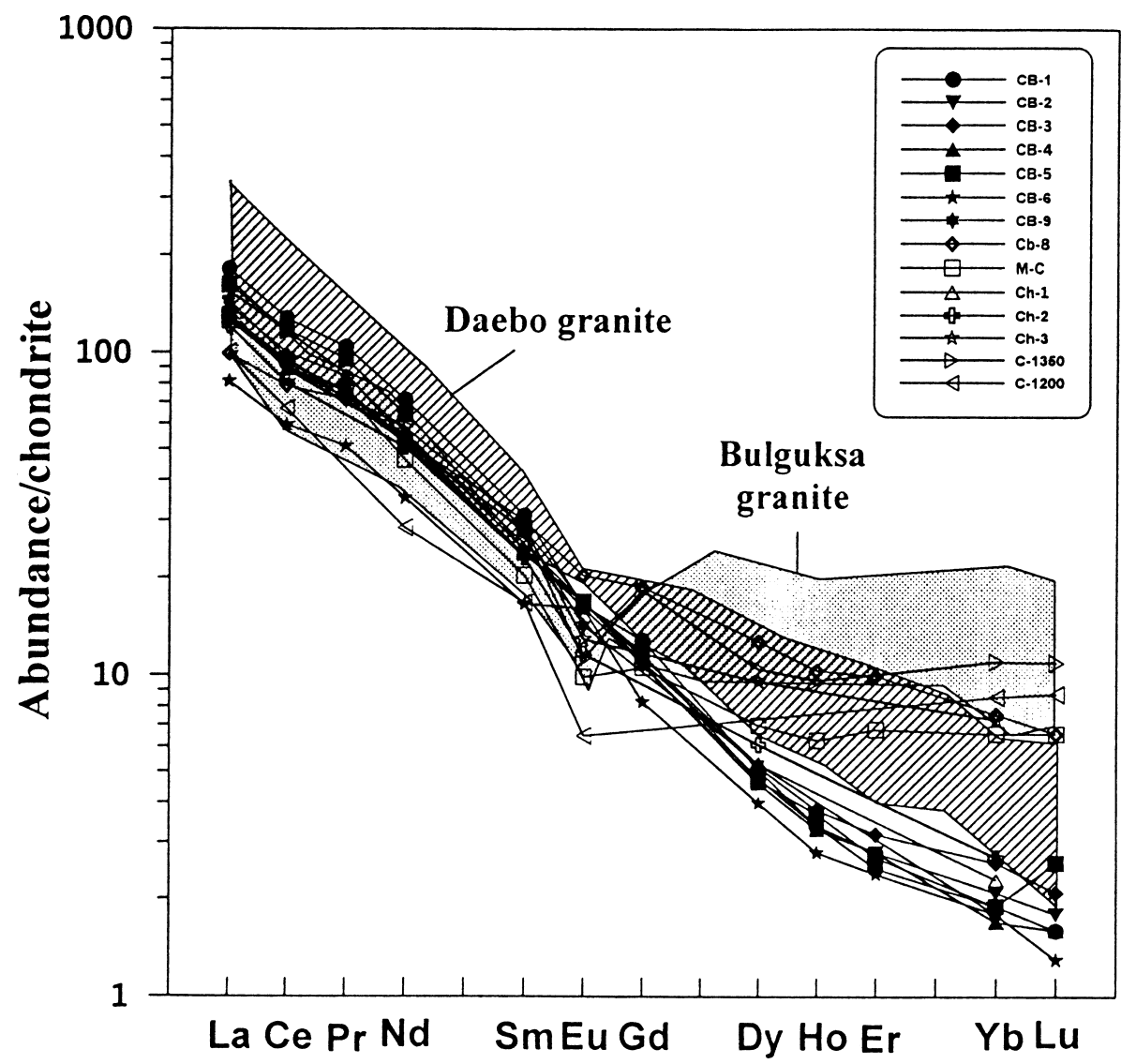

Fig. 8. Chondrite normalised REE patterns of granitic rocks from the Cheju volcanic island. REE abundances were normalised by the data of Nakamura (1974). The shadow and hatched fields represent the Bulguksa granite and the Daebo granite, respectively, in South Korea (Hong, 1987). 
REE patterns with marked Eu negative anomaly. This signature indicates the shallow emplacement of granitic magma which is originated from the mantle source materials (Kim et al., 1996). Lee (1992, 1994) and Cho and Kwon (1994) also pointed out that the Cretaceous granites in the Kyongsang basin have emplaced at shallow depth based on the petrographical and petrochemical data. The similarity in chemical composition and lithology of two groups of granitic rocks from the Cheju Island and the peninsula favors an interpretation of the similar petrogenetic setting for the whole Korean peninsula together with the island.

\section{Nd AND Sr ISOTOPES OF GRANITIC ROCKS}

Strontium and neodymium isotopes have much information to offer about magmatic processes as well as source rocks (Farmer and Depaolo, 1983; Roden et al., 1994; Kim et al., 1996; Wilson and Shimron, 2000). Analytical results of $\mathrm{Nd}$ and $\mathrm{Sr}$ isotopes for granitic rocks from the Cheju Island are given in Table 6. Homogeneous strontium isotopic compositions of feldspar $\left({ }^{87} \mathrm{Sr} /{ }^{86} \mathrm{Sr}=\right.$ $0.7174)$, hornblende $\left({ }^{87} \mathrm{Sr} /{ }^{86} \mathrm{Sr}=0.7167\right)$ and the host whole rock $\left({ }^{87} \mathrm{Sr} /{ }^{86} \mathrm{Sr}=0.7171\right)$ sample $(\mathrm{Sam}-$ ple No. CB-1) indicate that the Nd-Sr system seems to be little affected by later isotopic exchange with sea and/or meteoric waters during post-magmatic alteration processes. As shown in Table 6 , the ${ }^{87} \mathrm{Sr} /{ }^{86} \mathrm{Sr}$ ratio of granitic rocks from the Cheju island vary widely from 0.7108 to 0.7229 (avg. 0.7162). Especially granitic rocks in the Byeoldobong area known as the Jurassic age are characterized by high ${ }^{87} \mathrm{Sr} /{ }^{86} \mathrm{Sr}$ ratios ranging from 0.7116 to 0.7229 (initial ratio $\left({ }^{87} \mathrm{Sr} /{ }^{86} \mathrm{Sr}\right) \mathrm{i}=$ 0.7156 to $\left.0.7164, \varepsilon_{\mathrm{Sr}}=101 \sim 179\right)$. These strontium isotopic compositions are very similar to those of the Jurassic Daebo granites $\left(0.7111 \sim 0.7164, \varepsilon_{\mathrm{Sr}}=97 \sim 170\right.$, Kim et al., 1996) in the peninsula. On the other hand, the Cretaceous granite from the Hadeokcheon area (Sample No. M-C) has a relatively low ${ }^{87} \mathrm{Sr} /{ }^{86} \mathrm{Sr}$ value of 0.7108 (initial ratio $\left.\left({ }^{87} \mathrm{Sr} /{ }^{86} \mathrm{Sr}\right) \mathrm{i}=0.7077\right)$. This value falls in the isotopic range of the Cretaceous Bulguksa granite (initial ratio $\left({ }^{87} \mathrm{Sr} /{ }^{86} \mathrm{Sr}\right) \mathrm{i}=0.7042$ to

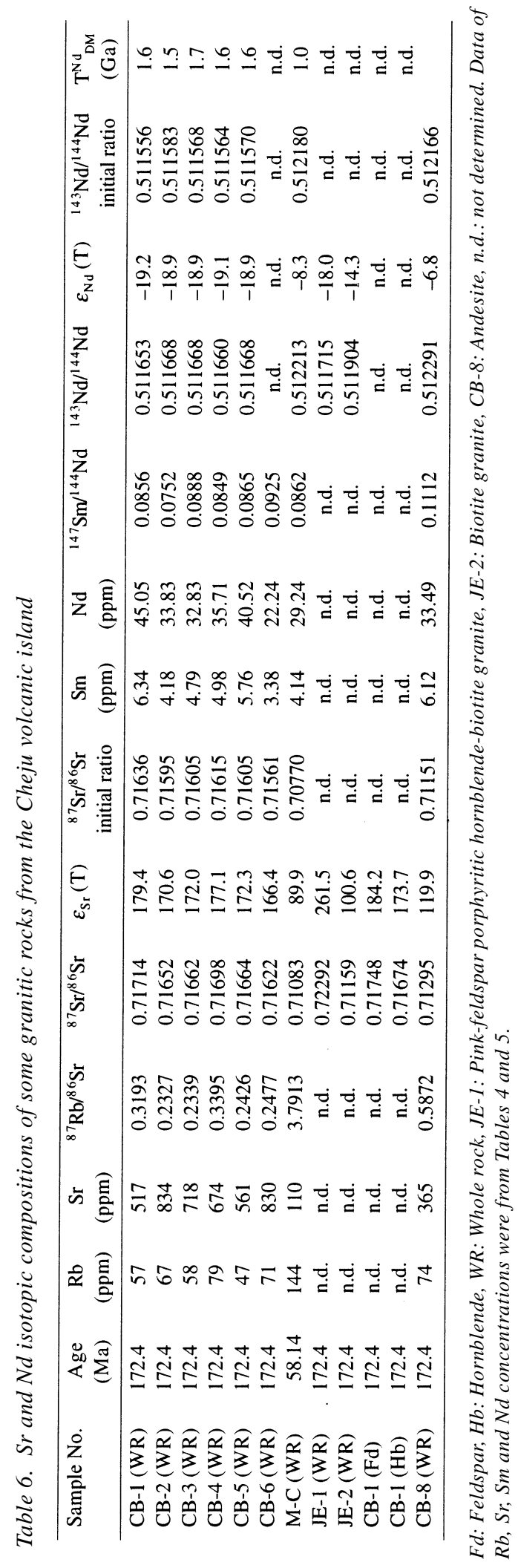




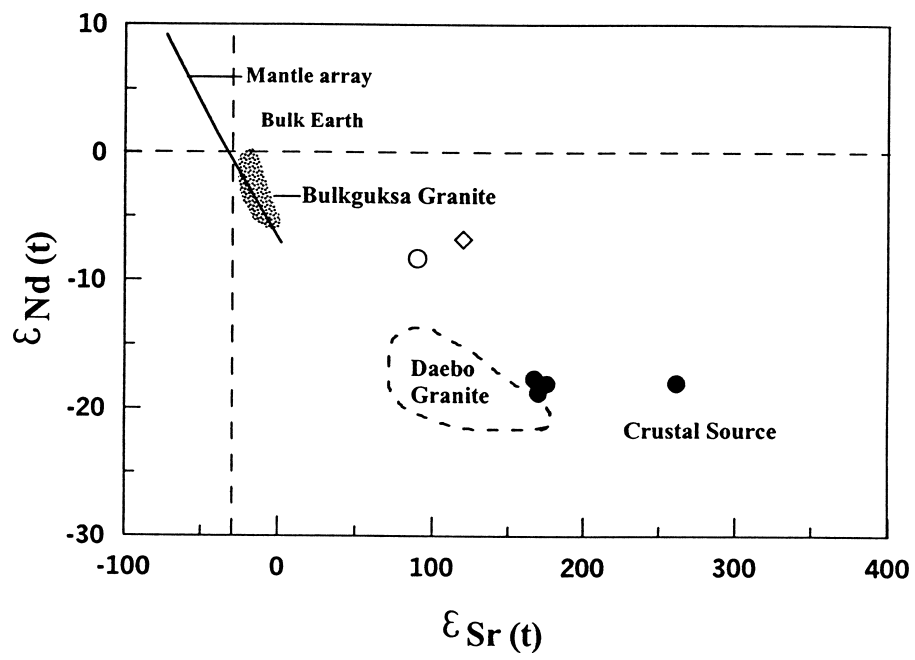

Fig. 9. $\varepsilon_{S r}(t) v s . \varepsilon_{N d}(t)$ of isotope correlation diagram of granitic rocks in the Cheju volcanic island. Isotope data for Daebo granite (dashed area) and Bulkuksa granite (shaded area) (Kim et al., 1996) and volcanic rocks, Cheju island (Kim et al., 1999). Symbols are the same as in Fig. 6. Diamond symbol indicates andesite (Sample No. CB-8).

0.7067, Kim et al., 1996). Rb and Sr in the Jurassic granitic rocks from the Cheju Island varies from 47 to $79 \mathrm{ppm}$ and 561 to $834 \mathrm{ppm}$, respectively. According to Kim et al. (1996), the Jurassic Daebo granites from the peninsula show large range in $\mathrm{Rb}$ (56.8 to $182.4 \mathrm{ppm}$ ) and $\mathrm{Sr}$ (18 to $762.7 \mathrm{ppm}$ ). The Cretaceous granite from the Hadeokcheon area have $144 \mathrm{pm}$ of $\mathrm{Rb}$ and $110 \mathrm{ppm}$ of $\mathrm{Sr}$, which are fall in the range of the Cretaceous Bulguksa granite in the peninsula $(\mathrm{Rb}=89.7 \sim 314.4 \mathrm{ppm}$, $\mathrm{Sr}=44.4 \sim 308.0 \mathrm{ppm}$, Kim et al., 1996).

The ${ }^{143} \mathrm{Nd} /{ }^{144} \mathrm{Nd}$ ratios of the Jurassic granites from the Byeoldobong area range from 0.51165 to $0.51190\left(\varepsilon_{\mathrm{Nd}}=-19 \sim-14\right)$, and fall in the range of the Daebo granite $\left(\varepsilon_{\mathrm{Nd}}=-19 \sim-10\right.$, Kwon and Tilton, 1992; $\varepsilon_{\mathrm{Nd}}=-21 \sim-14$, Kim et al., 1996) (Fig. 9). Meanwhile the Cretaceous granite from the Hadeokcheon area has ${ }^{143} \mathrm{Nd} /{ }^{144} \mathrm{Nd}$ value $=$ 0.51221 (initial ratio $\left({ }^{143} \mathrm{Nd} /{ }^{144} \mathrm{Nd}\right) \mathrm{i}=0.51218$, $\left.\varepsilon_{\mathrm{Nd}}=-8.3\right)$. This value is compared to the Cretaceous equivalent ( $\varepsilon_{\mathrm{Nd}}=-6.6$ to 0.4$)$ in the Okcheon zone. The Jurassic Byeoldobong granites have slightly higher concentrations of $\mathrm{Nd}$ (22.2 45.05 ppm) and Sm (3.38 6.34 ppm) than those of the Cretaceous Hadeokcheon granite $(\mathrm{Nd}=29.24$ $\mathrm{ppm}, \mathrm{Sm}=4.14 \mathrm{ppm})$. However, the $\mathrm{Sm}$ and $\mathrm{Nd}$ contents of the Daebo granites $(\mathrm{Sm}=3.7 \sim 13.8$ ppm, $\mathrm{Nd}=18.0 \sim 34.0 \mathrm{ppm}$ ) have roughly the same range as those of the Bulguksa granites $(\mathrm{Sm}=$ 1.7 7.1 ppm, $\mathrm{Nd}=7.0 \sim 34.0 \mathrm{ppm})($ Kim et al., 1996).

Based on the plots of $\varepsilon_{\mathrm{Sr}}$ versus $\varepsilon_{\mathrm{Nd}}$, Kim et al. (1996) suggested that the Cretaceous granitic rocks in the Kyoungsang basin were derived from a mantle source. On the other hand, the Jurassic ones were interpreted as partial melting products of lower crustal material and/or material with significant crustal contribution in mantle derived components (Kim et al., 1996). The $\mathrm{Nd}-\mathrm{Sr}$ isotopic and $\mathrm{Rb}-\mathrm{Sr}$ concentration data of granitic rock from the Cheju island provides a similar source regime of calc alkaline magma in the peninsula.

Calculated $\mathrm{T}^{\mathrm{Nd}}{ }_{\mathrm{DM}}$ model ages are given in Table 6. The $\mathrm{T}^{\mathrm{Nd}}{ }_{\mathrm{DM}}$ model ages from Jurassic granites in Cheju island range from 1.1 to $1.7 \mathrm{Ga}$ (avg. $1.5 \mathrm{Ga})$, corresponding to middle Proterozoic age. Inferred model ages agree with those of Jurassic granites (1.5 to $2.3 \mathrm{Ga}$, Kwon and Tilton, 1992; 1.7 to $1.9 \mathrm{Ga}$, Kim et al., 1996) in the Okchon zone in the peninsula. On the other hand, Cretaceous granite (Sample No. M-C) yielded a little younger model age of $1.0 \mathrm{Ga}$ (Table 6). These model ages suggest that a Proterozoic basement exist beneath the Cheju volcanic island and the 
Mesozoic plutons in the island have evolved since mid-Proterozoic time in accordance with those of the peninsula.

\section{DISCUSSION}

The basement of Cheju volcanic island has been considered to be made of Cretaceous volcanics and granitic rocks and to be the extension of the Kyoungsang sedimentary basin of the peninsula (Lee, 1982; Koh et al., 1993; Sohn and Yoon, 1995). However, in this study, the Jurassic granites were firstly identified by K-Ar and CHIME dating of the granite xenoliths from the pyroclastic formation of the Byeoldobong area in the vicinity of Cheju city. This finding is very important in correlating the basement geology to that in the Korean peninsula. The ages of the granites in the Cheju island correspond to those of the Jurassic Daebo and Cretaceous Bulguksa granites. In addition, geochemical and $\mathrm{Nd}-\mathrm{Sr}$ isotopic data for the granites in the Cheju island also evidently indicate the presence of two groups which correspond to above two (Figs. 6 and 9).

The Korean peninsula located at the eastern margin of the Sino-Korean craton is widely underlain by a Precambrian metamorphic basement. Based on the geology and tectonic framework, South Korea is divided into five geological provinces: (1) Gyonggi massif, composed mainly of Precambrian metamorphic rocks and Jurassic granites, (2) Okchon zone composed mainly of Precambrian to Cretaceous metamorphic and sedimentary rocks and Jurassic to Cretaceous granitic rocks, (3) Ryeongnam massif composed mainly of Precambrian metamorphic rocks and Permian to Cretaceous igneous rocks, (4) Kyongsang sedimentary basin, consisting of Cretaceous sedimentary and igneous rocks and (5) Tertiary sedimentary and volcanic basin, including the Cheju and Ulreung volcanic islands (Fig. 1).

Four plausible candidates for the basement rock of the Cheju volcanic island can be made. (1) Cretaceous sedimentary and igneous rocks of the Kyoungsang basin, (2) metasedimentary and igneous rocks of the Okchon zone (3) Precambrian metamorphic rocks and Permian to Jurassic granitic rocks of the Ryeongnam massif and (4) oceanic basaltic rocks of the Tertiary volcanic basin.

(1) Many previous workers (e.g., Haraguchi, 1929; Ahn et al., 1995; Lee, 1996; Koh, 1997; Yoon, 1997) proposed that the basement rocks of the Cheju Island could be Cretaceous volcanogenic sedimentary and igneous rocks in the Kyoungsang basin. This hypothesis has been strongly supported by the identification of Cretaceous granites in the Haduckcheon and Manjang tunnel areas, which have petrographic features quite similar to those of micrographic granites in the Kyoungsang basin. However, no Jurassic granite and/or Precambrian metamorphic rocks are present in this basin.

(2) Occurrence of the Jurassic granites in the Cheju volcanic island provides a significant constraint on this problem. These granites have $\mathrm{Nd}$ and $\mathrm{Sr}$ isotopic signatures, $\mathrm{Nd}$ model ages and geochemical characteristics similar to those of the Jurassic Daebo granite in the Korean peninsula. In contrast, $\mathrm{Nd}$ and $\mathrm{Sr}$ isotopoic compositions of the Cretaceous granites in the island are similar to those of the Cretaceous granites in the peninsula. In the Cheju island, presence of Jurassic and Cretaceous granitoids with geochemical and isotopical characteristics comparable to those of Daebo and Bulkuksa granites, respectively is a strong evidence for the correlation of the continental basement with the Okchon zone. The basement of Okchon zone consists mainly of metasedimentary rocks such as gneiss and schist of Precambrian age. The Jurassic and Cretaceous granitic rocks have emplaced in the metasedimentary rocks. Present geologic informations on basement rocks in Cheju volcanic island provide, to a large extent, a consistency of basement rock types in lithological and chronological aspects between the island and the Okchon zone.

(3) The Ryeongnam massif is represented by Precambrian gneiss and Permian to Jurassic granites (Lee et al., 1997, 1998). Cretaceous volcanic and sedimentary rocks are limited. Thus the geology of this massif is different from the basement geology of the Cheju island. 
(4) Oceanic basaltic crust in the Cheju island is discarded because of the occurrence of Mesozoic granitic rocks and Precambrian gneiss fragments in some volcanic sequences. Crust-mantle boundary was estimated to be at depth of $c a$. $40 \mathrm{~km}$ by the olivine-clinopyroxene geobarometer (Choi et al., 2000).

On the basis of the geological and tectonic provinces, Kim (1975) reported that the Cheju island belongs to Tertiary basin as shown in Fig. 1. However, combined geochemical and $\mathrm{Nd}-\mathrm{Sr}$ isotopical characteristics and radiometric ages of the granitic rocks from Cheju Island indicate that the basement of the island is correlated with the Okchon zone rather than the Kyoungsang sedimentary basin. In addition, calculated $\mathrm{T}^{\mathrm{Nd}} \mathrm{DM}$ model ages ranging from 1.1 to $1.7 \mathrm{Ga}$ for the Jurassic granites in the island are also comparable to those of Jurassic granites $(1.7$ to $1.9 \mathrm{Ga}$, Kim et al., 1996) in the Okchon zone in the peninsula. Thus, it is suspected that the Okchon zone, known as a highly mobile belt (Kim, 1970; Cluzel, 1991), extends to the south China block through the Cheju island. Most Korean geologists (e.g., Lee, 1982; Won et al., 1986; Park and Kwon, 1993; Park, 1994; Park et al., 1996; Chough et al., 2000) have believed that the Cheju alkali volcanism was originated from intraplate hot spots beneath the Tertiary sedimentary and volcanic basin. However, in the tectonic view point, we are led to conclude that the Cheju alkali volcanism occurred in close relation to the tectonism of the Okchon folded belt. Occurrence of Tertiary basalt flow with lots of lehzerite mante xenoliths from the Jokokri in the Okchon zone (Kim et al., 1988) can also support the above conclusion.

\section{CONCLUSION}

Granitic xenoliths including biotite granite, porphyritic hornblende-biotite granite and two mica granite from the pyroclastic formation of the Byeoldobong area and granite core samples from the Hadeokcheon area were used to investigate the petrochemistry, evolution and age of emplacement of the plutonic rocks.
Dating of the porphyritic hornblende-biotite granites yielded a biotite K-Ar age of $172.4 \pm 5.2$ $\mathrm{Ma}$ and CHIME ages ranging from $169 \pm 29 \mathrm{Ma}$ to $183 \pm 40 \mathrm{Ma}$. These are concordant with each other, and indicate the Jurassic plutonic activity during the Daebo orogeny.

Geochemical and Nd-Sr isotopic signatures of Jurassic granite xenoliths from the Beoldobong area are comparable to those of the Jurassic Daebo granites in the Korean peninsula. On the other hand, Cretaceous micrographic granites from the Hadeokcheon and Manjang tunnel areas, in terms of lithological, chronological, geochemical and isotopical characteristics, correspond to those of the Cretaceous granite in the peninsula. These suggest that the basement of Cheju volcanic island had experienced the same plutonic activities as those in the peninsula, especially in the Okchon zone. Furthermore, the Nd model ages for the granitic plutons in the island ranging from 1.0 to 1.7 $\mathrm{Ga}$ imply that the basement of the island has evolved since mid-Proterozoic time as in the Okchon zone of the peninsula. In the view of tectonic division, the Cheju volcanic island possibly belongs to the intraplate Okchon zone lying on the southeast continental margin of the Eurasian plate.

Acknowledgments-This work was supported by Korea Research Foundation Grant (KRF-2001-00791) and the Korea Science Foundation to Kim Kyu Han. We thanks professor Yun, J. S. of Cheju National University for his help during the sample collection and Yogo, S. of Nagoya University for preparation of thin sections. Thanks are extended to Sung-Eun Lee and Ji Hye Song who assisted us in drafting.

\section{REFERENCES}

Ahn, K. S., Lee, H. K. and Lin, H. C. (1995) A petrological and geochemical study of granites in the Cheju Island. Econ. Environ. Geol. 28, 513-518 (in Korean with English abstract).

Bence, A. E. and Albee, A. L. (1968) Empirical correction fators for the elelctron microanalysis of silicates and oxides. J. Geol. 76, 382-403.

Cho, D. L. and Kwon, S. T. (1994) Hornblende geobarometry of the Mesozoic granitoids in South Korea and the evolution of crustal thickness. J. Geol. 
Soc. Korea 30, 41-61 (in Korean with English abstract).

Choi, S. H., Jwa, Y. J. and Lee, H. Y. (2000) A geothermal gradient of the upper mantle beneath Jejudo, Korea: evidence from mantle xenoliths. Annual Meeting of Petrological Society of Korea and Mineralogical Society of Korea (Abstract), p. 19.

Chough, S. K., Kwon, S. T., Ree, J. H. and Choi, D. K. (2000) Tectonic and sedimentary evolution of the Korean peninsula: a review and new view. Earth Science Review 52, 175-235.

Cluzel, D. (1991) The Ogcheon belt (Republic of Korea): Tectonic and geodynamics of the polycyclic intraplate domain. J. Geol. Soc. Korea 27(5), 515519.

Dosso, L. and Murthy, V. R. (1980) A Nd isotope study of the Kerguelen islands: inferences on enriched oceanic mantle sources. Earth Planet. Sci. Lett. 48, 268276.

Farmer, G. L. and DePaolo, D. J. (1983) Origin of Mesozoic and Tertiary granite in the western U. S. and implications for pre-Mesozoic crustal structure. I. $\mathrm{Nd}$ and $\mathrm{Sr}$ isotopic studies in the geocline of the northern Great Basin. J. Geophys. Res. 88, 379-401.

Haraguchi, K. (1929) Granite xenolith in the pyroclastic formation of the Beoldobong area. Chikyu 12, 9499.

Hong, Y. K. (1987) Geochemical characteristics of Precambrian, Jurassic and Cretaceous granites in Korea. J. Korean Inst. Mining Geol. 20, 35-60.

Jacobsen, S. B. and Wasserburg, G. J. (1980) Sm-Nd evolution of chondrites. Earth Planet. Sci. Lett., 90, 315-329.

KIGAM (1995) Isotope age map of volcanic rocks in Korea. Institute of Geology, Mining and Materials, Korea, p. 1.

Kim, K. H. (1992) Geochemical study of some Mesozoic granitic rocks in South Korea. J. Korean Inst. Mining Geol. 25, 435-446.

Kim, K. H., Park, S. S. and Na, C. K. (1996) Nd and Sr isotopic signatures of Mesozoic granitoids in South Korea. Resource Geol. 46, 215-226.

Kim, K. H., Tanaka, T., Nagao, K. and Jang, S. K. (1999) $\mathrm{Nd}$ and $\mathrm{Sr}$ isotopes and $\mathrm{K}-\mathrm{Ar}$ ages of the Ulreungdo alkali volcanic rocks in the East Sea, South Korea. Geochem. J. 33, 317-341.

Kim, O. J. (1970) Geology and Tectonics of the midcentral region of South Korea. J. Korean Inst. Mining Geol. 2(4), 73-90.

Kim, O. J. (1975) Granite and tectonics of South Korea. J. Korean Inst. Mining Geol. 8(4), 223-230.

Kim, Y. K., Lee, D. S. and Song, Y. K. (1988) Petrology of ultramafic nodules in Jokokri basalt, Boun area. J. Geol. Soc. Korea 24, 57-66.

Koh, G. W. (1997) Characteristic of the groundwater and hydrogeologic implication of the Seoguipo Formation in Cheju Island. Ph.D. Thesis, Pusan National Univ., 325 pp. (in Korean with English abstract).

Koh, G. W., Park, W. B., Kim, S. H., Oh, S. S. and Yoon, S. (1982) Study on the subsurface geologic structure, groundwater level fluctuation and groundwater quality of the eastern area of Cheju Island. Report of the Institute of Health and Environment of Cheju Island 3, 15-43 (in Korean).

Koh, G. W., Park, W. B., Yoon, J. S., Ko, Y. G., Kim, S. H., Shin, S. J., Song, Y. C. and Yoon, S. (1993) Study on characteristics of water quality and occurrence types of groundwater in east and west area, Cheju Island. Report of the Institute of Health and Environment of Cheju Island 4, 191-222 (in Korean).

Kwon, S. T. and Tilton, G. R. (1992) Nd-Sr isotope study Phanozoic granitoids in South Korea: Implications for basement structure and tectonics of East Asia. Proceedings 3(1), IGC 29th Kyoto, p. 109.

Lee, D. Y., Yun, S. K., Kim, J. Y. and Kim, Y. J. (1988) Quaternary geology of the Jeju Island. Korea Institute of Energy and Resources Report, KR-87-29, 233 278 (in Korean).

Lee, J. I. (1992) Mineralogical and petrography of the shallow depth emplaced granitic rocks distributed in the southern part of the Kyeongsang basin, Korea. $J$. Korean Earth Sci. Soc. 13, 176-199.

Lee, J. I. (1994) Major and trace element geochemistry of the shallow-depth emplaced granitic rocks, southeastern part of the Kyeongsang basin, Korea. J. Geol. Soc. Korea 30(5), 482-496.

Lee, J. I., Jwa, Y. J., Kagami, H. and Uchiumi, S. (1997) New radiometric ages of the granitic rocks in the Yeongnam massif. 30th Annual Meeting of Korea Society of Economic and Environmental Geology (Abstract) Kwangju, April 25-26, 61-62.

Lee, J. I., Jwa, Y. J., Park, C. H., Lee, M. J. and Moutte, J. (1998) Petrology and geochemistry of the Yeongju and Andong granites in the northeastern Yeongnam massif Korea. Geoscience Journal 2, 1-14.

Lee, J. S. (1989) Petrology and tectonic setting of the Cretaceous to Cenozoic volcanics of South Korea: Geodynamic implications on the East-Eurasian margin. Ph.D. Thesis, University D'orleans, 254 pp.

Lee, M. W. (1982) Petrology and geochemistry of Jeju volcanic island, Korea. Sci. Rep., Tohoku Univ., Ser., 315, 177-256.

Lee, M. W., Won, C. K., Lee, D. Y. and Park, G. H. (1994) Stratigraphy and petrology of volcanic rocks in southern Cheju Island, Korea. J. Geol. Soc. Korea. 30, 521-541.

Lee, S. K. (1996) Exploration and feasibility study for geothermal potential in Cheju island (III). Ministry of Trade, Industry and Energy, Report, 951K101113AG1, 23-28 (in Korean). 
Michard, A., Gurriet, P., Soudant, M. and Albarede, F. (1985) Nd isotopes in French phanerozoic shale: external aspects of crustal evolution. Geochim. Cosmochim. Acta 49, 601-610.

Min, K. D., Kim, O. J. and Yun, S. (1988) Applicability of plate tectonics to the post late Cretaceous igneous activity and mineralization in the southern part of southern Korea (II): J. Geol. Soc. Korea 24, 1140 (in Korean with English abstract).

Nakamura, N. (1974) Determination of REE, Ba, Fe, $\mathrm{Mg}, \mathrm{Na}$ and $\mathrm{K}$ in carbonaceous and ordinary chondrites. Geochim. Cosmochim. Acta 38, 757-773.

Park, J. B. (1994) Geochemical evolution of the Cheju volcanic island, Korea. Ph.D. Thesis, Yonsei Univ., Seoul, Korea, 303 pp. (in Korean).

Park, J. B. and Kwon, S. T. (1993) Geochemical evolution of the Cheju volcanic island: Trace element chemistry of volcanic rocks from the northern part of Cheju island. J. Geol. Soc. Korea 29, 477-492 (in Korean with English abstract).

Park, J. B., Park, K. H. and Cheong, C. S. (1996) Sr$\mathrm{Nd}-\mathrm{Pb}$ isotopic compositions of lavas from Cheju island, Korea. J. Petrol. Soc. Korea 5. 89-107.

Roden, M. F., Trull, T., Hart, S. R. and Frey, F. A. (1994) New $\mathrm{He}, \mathrm{Nd}, \mathrm{Pb}$, and $\mathrm{Sr}$ isotopic constraints on the constitution of Hawaiian plume: Result from Kooolau volcano, Oahu, Hawaii, USA. Geochim. Cosmochim. Acta 58, 1431-1440.

Scharer, U., Hanet, J. and Allegro, C. J. (1984) The Transhimalaya (Gangdese) plutonism in the Ladakh region: a U-Pb and $\mathrm{Rb}-\mathrm{Sr}$ study. Earth Planet. Sci. Lett. 67, 327-339.

Smellie, J. A. T., Cogger, N. and Herrinton, J. (1978) Standards for quantitative microprobe determination of uranium and thorium with additional information on the chemical formulae of davidite and euxenitepolycrase. Chem. Geol. 22, 1-10.

Sohn, Y. K. and Yoon, S. H. (1995) Marine and volcaniclastic sequences in Cheju island, Korea. Third International Conference on Asian Marine Geology. Field Excursion Guidebook, 1-5.

Son, I. S. (1997) Lithostratigraphy and chronostratigraphy of Cheju Island, Korea. Ph.D. Thesis, Cheju National Univ., 213 pp. (in Korean with English abstract).

Suzuki, K. and Adachi, M. (1991) The chemical Th-Utotal $\mathrm{Pb}$ isochron ages of zircon and monazite from the gray granite of the Hida Terrane, Japan. J. Earth. Sci. Nagoya Univ. 38, 11-37.

Suzuki, K. and Adachi, M. (1998) Denudation history of the high T/P Ryoke metamorphic belt, southwestern Japan: constraints from CHIME monazite ages of gneisses and granitoids. J. Metamorphic Geol. 16, 23-37.
Suzuki, K., Adachi, M. and Kajizuka, I. (1994) Electron microprobe observations of $\mathrm{Pb}$ diffusion in metamorphosed detrital monazites. Earth Planet. Sci. Lett. 128, 391-405.

Suzuki, K., Adachi, M. and Nareki, T. (1996) CHIME age dating of monazites from metamorphic rocks and granitic rocks of the Ryoke belt in the Iwakuni area, southwest Japan. Island Arc 5, 43-55.

Takeuchi, M. and Suzuki, K. (2000) Permian CHIME ages of leucocratic tonalite clasts from middle Permian Usuginu-type conglomerate in the South Kitakami Terrane, Northeastern Japan. J. Geol. Soc. Japan 106, 812-815.

Yoon, S. (1997) Miocene-Pleistocene volcanism and tectonics in southern Korea and their relationship to the opening of the Japan Sea. Tectonophysics 281, 53-70.

Yoon, S., Koh, G. W. and Kim, I. T. (1995a) Development history of Cheju Island. Chejudo (Bull. Chejudo Prov. Geovern.) 98, 148-164.

Yoon, S. H., Sohn, Y. K. and Han, S. J. (1995b) Marine and volcaniclastic sequences in Cheju Island, Korea. Third International Conference on Asian Marine Geology. Field Excursion Guidebook, 1-4.

Yun, S. H., Lee, Y. J. and Chung, W. W. (1998) Petrology and zircon crystal morphology of the granite rocks from the basement, Cheju volcanic island, Korea: (I) Cretaceous granite. J. Korean Earth Sci. Soc. 19, 486-494 (in Korean with English abstract).

Yun, S. H., Lee, Y. J., Chung, W. W. and Koh, J. S. (1999) Petrology and zircon crystal morphology of the granitic rocks from the basement, Cheju volcanic island, Korea: (II) Pre-Cretaceous granite. J. Korean Earth Sci. Soc. 20, 277-281.

Yun, S. K. and Kim, W. Y. (1984) Geothermal research in Cheju Island. Korea Institute of Energy and Resources Report 83-5-08, 110-135 (in Korean).

Yun, S. K., Han, D. S. and Lee, D. Y. (1987) Quaternary geology in the southern part of Jeju Island. Korea Institute of Energy and Resource Report KR86-2-(B)-2, 64 pp. (in Korean).

Wasserburg, G. J., Jacobsen, S. B., DePaolo, D. J., McCulloch, M. J. and Wen, T. (1981) Precise determination of $\mathrm{Sm} / \mathrm{Nd}$ ratios, $\mathrm{Sm}$ and $\mathrm{Nd}$ isotopic abundances in standard solutions. Geochim. Cosmochim. Acta 45, 2311-2324.

Wilson, M. and Shimron, A. E. (2000) Early Cretaceous magmatism of Mount Hermon, Northern Israel. Contrib. Mineral. Petrol. 139, 54-67.

Won, J. K., Matsuda, J., Nagao K., Kim, K. H. and Lee, M. W. (1986) Paleomagnetism and radiometric age of trachytes in Jeju Island, Korea. J. Korean Inst. Mining Geol. 19, 25-33 (in Korean with English abstract). 


\section{APPENDIX}

Table A1. Summary of K-Ar age data of volcanic rocks from the Cheju volcanic Island

\begin{tabular}{|c|c|c|c|c|}
\hline Sample No. & Rock type & & Age (Ma) & Reference \\
\hline DH-1 & Mugearite & $\mathrm{wr}$ & $0.618 \pm 0.017$ & Lee et al. (1994) \\
\hline $14-1$ & Benmorite & $\mathrm{wr}$ & $0.711 \pm 0.021$ & Lee et al. (1994) \\
\hline $26-2$ & Basalt & wr & $0.121 \pm 0.018$ & Lee et al. (1994) \\
\hline $\mathrm{P} 1$ & Basalt & - & $2.22 \pm 0.16$ & Yoon et al. (1995a) \\
\hline $\mathrm{C} 15$ & Basalt & $\mathrm{wr}$ & 0.16 & KIGAM (1995) \\
\hline $\mathrm{C} 39$ & Basalt & wr & 0.16 & KIGAM (1995) \\
\hline $\mathrm{C} 1$ & Trachyte & $\mathrm{wr}$ & 0.025 & KIGAM (1995) \\
\hline $\mathrm{C} 13$ & Basalt & wr & 0.07 & KIGAM (1995) \\
\hline $\mathrm{C} 14$ & Basalt & $\mathrm{wr}$ & 0.47 & KIGAM (1995) \\
\hline $\mathrm{C} 37$ & Basalt & $\mathrm{wr}$ & 0.05 & KIGAM (1995) \\
\hline $\mathrm{C} 26$ & Basalt & $\mathrm{wr}$ & 0.27 & KIGAM (1995) \\
\hline $\mathrm{C} 38$ & Basalt & wr & 0.60 & KIGAM (1995) \\
\hline $\mathrm{C} 12$ & Basalt & wr & 0.63 & KIGAM (1995) \\
\hline $\mathrm{C} 35$ & Basalt & $\mathrm{wr}$ & 0.70 & KIGAM (1995) \\
\hline $\mathrm{C} 17$ & Basalt & $\mathrm{wr}$ & 0.31 & KIGAM (1995) \\
\hline $\mathrm{C} 33$ & Basalt & $\mathrm{Fd}$ & 0.11 & KIGAM (1995) \\
\hline $\mathrm{C} 29$ & Basalt & wr & $0.37,0.51$ & KIGAM (1995) \\
\hline $\mathrm{C} 28$ & Basalt & wr & $0.12,0.15$ & KIGAM (1995) \\
\hline $\mathrm{C} 27$ & Basalt & $\mathrm{wr}$ & $0.17,0.18$ & KIGAM (1995) \\
\hline $\mathrm{C} 18$ & Trachyte & wr & 0.50 & KIGAM (1995) \\
\hline $\mathrm{C} 16$ & Basalt & $\mathrm{wr}$ & 0.55 & KIGAM (1995) \\
\hline $\mathrm{C} 3$ & Trachyte & wr & 0.73 & KIGAM (1995) \\
\hline $\mathrm{C} 4$ & Trachyte & $\mathrm{wr}$ & 0.73 & KIGAM (1995) \\
\hline C6 & Trachyandesite & $\mathrm{wr}$ & 0.41 & KIGAM (1995) \\
\hline $\mathrm{C} 20$ & Trachyte & wr & $0.17,0.19$ & KIGAM (1995) \\
\hline $\mathrm{C} 24$ & Basalt & $\mathrm{wr}$ & 0.10 & KIGAM (1995) \\
\hline C19 & Trachyte & wr & $0.89,0.92$ & KIGAM (1995) \\
\hline $\mathrm{C} 43$ & Basalt & $\mathrm{wr}$ & 1.20 & KIGAM (1995) \\
\hline C9 & Basalt & $\mathrm{wr}$ & 0.6 & KIGAM (1995) \\
\hline $\mathrm{C} 7$ & Basalt & $\mathrm{wr}$ & 0.035 & KIGAM (1995) \\
\hline $\mathrm{C} 8$ & Basalt & $\mathrm{wr}$ & 0.07 & KIGAM (1995) \\
\hline $\mathrm{C} 2$ & Trachyte & wr & 0.75 & KIGAM (1995) \\
\hline $\mathrm{C} 10$ & Trachyte & $\mathrm{wr}$ & 0.87 & KIGAM (1995) \\
\hline $\mathrm{C} 25$ & Basalt & $\mathrm{wr}$ & 1.20 & KIGAM (1995) \\
\hline $\mathrm{C} 44$ & Tachyte & $\mathrm{wr}$ & 0.94 & KIGAM (1995) \\
\hline $\mathrm{C} 15$ & Basalt & wr & 0.52 & KIGAM (1995) \\
\hline $\mathrm{C} 21$ & Basalt & $\mathrm{wr}$ & $0.69,0.71$ & KIGAM (1995) \\
\hline $\mathrm{C} 36$ & Basalt & $\mathrm{wr}$ & 0.16 & KIGAM (1995) \\
\hline $\mathrm{C} 42$ & Basalt & $\mathrm{wr}$ & 0.17 & KIGAM (1995) \\
\hline $\mathrm{C} 22$ & Basalt & $\mathrm{wr}$ & $1.19,0.12$ & KIGAM (1995) \\
\hline SYU & Basalt & wr & 0.07 & Kimetal. (1999) \\
\hline SYL & Basalt & $\mathrm{wr}$ & 0.02 & Kimet al. (1999) \\
\hline SPU & Basalt & wr & 0.84 & Kimet al. (1999) \\
\hline
\end{tabular}

wr: whole rock, Fd: feldspar. 